\title{
Fibrinolysis is essential for fracture repair and prevention of heterotopic ossification
}

\author{
Masato Yuasa, ${ }^{1,2}$ Nicholas A. Mignemi, ${ }^{1,3}$ Jeffry S. Nyman, ${ }^{1,4,5,6}$ Craig L. Duvall, ${ }^{4}$ Herbert S. Schwartz, ${ }^{1,3}$ Atsushi Okawa, ${ }^{2}$ \\ Toshitaka Yoshii, ${ }^{2}$ Gourab Bhattacharjee, ${ }^{7}$ Chenguang Zhao, ${ }^{7}$ Jesse E. Bible, ${ }^{1}$ William T. Obremskey, ${ }^{1}$ Matthew J. Flick, ${ }^{8}$ \\ Jay L. Degen, ${ }^{8}$ Joey V. Barnett, ${ }^{9}$ Justin M.M. Cates, ${ }^{3}$ and Jonathan G. Schoenecker ${ }^{1,3,5,9,10}$ \\ DDepartment of Orthopaedics, Vanderbilt University Medical Center, Nashville, Tennessee, USA. ${ }^{2}$ Department of Orthopaedic Surgery, Tokyo Medical and Dental University, Tokyo, Japan.
${ }^{3}$ Department of Pathology, ${ }^{4}$ Department of Biomedical Engineering, and ${ }^{5}$ Center for Bone Biology, Vanderbilt University Medical Center, Nashville, Tennessee, USA. ${ }^{6}$ Department of Veterans Affairs,
Tennessee Valley Healthcare System, Nashville, Tennessee, USA. ${ }^{7}$ ISIS Pharmaceuticals Inc., Carlsbad, California, USA. ${ }^{8}$ Division of Experimental Hematology and Cancer Biology,
Cincinnati Children's Hospital Medical Center, Cincinnati, Ohio, USA. ${ }^{9}$ Department of Pharmacology and ${ }^{10}$ Department of Pediatrics, Vanderbilt University Medical Center, Nashville, Tennessee, USA.
}

Bone formation during fracture repair inevitably initiates within or around extravascular deposits of a fibrin-rich matrix. In addition to a central role in hemostasis, fibrin is thought to enhance bone repair by supporting inflammatory and mesenchymal progenitor egress into the zone of injury. However, given that a failure of efficient fibrin clearance can impede normal wound repair, the precise contribution of fibrin to bone fracture repair, whether supportive or detrimental, is unknown. Here, we employed mice with genetically and pharmacologically imposed deficits in the fibrin precursor fibrinogen and fibrin-degrading plasminogen to explore the hypothesis that fibrin is vital to the initiation of fracture repair, but impaired fibrin clearance results in derangements in bone fracture repair. In contrast to our hypothesis, fibrin was entirely dispensable for long-bone fracture repair, as healing fractures in fibrinogen-deficient mice were indistinguishable from those in control animals. However, failure to clear fibrin from the fracture site in plasminogen-deficient mice severely impaired fracture vascularization, precluded bone union, and resulted in robust heterotopic ossification. Pharmacological fibrinogen depletion in plasminogen-deficient animals restored a normal pattern of fracture repair and substantially limited heterotopic ossification. Fibrin is therefore not essential for fracture repair, but inefficient fibrinolysis decreases endochondral angiogenesis and ossification, thereby inhibiting fracture repair.

\section{Introduction}

Mechanistically, fracture repair occurs through both intramembranous and endochondral ossification, the same biological processes that occur in bone development $(1,2)$. However, in contrast to bone development, bone formation during fracture repair initiates within a vastly different microenvironment that develops secondary to tissue injury and hemorrhage. As a result, fracture healing inevitably initiates within or around extravascular fibrin deposits that are distributed throughout the injury. Previous studies have suggested that intrinsic elements of the fibrin matrix are essential for initiating bone formation (3). Proposed molecular mechanisms include the following: (a) acting as a reservoir for growth factors and vasoactive molecules from platelets (4-6), (b) promoting influx of inflammatory and mesenchymal progenitor cells through specific integrin/ receptor interactions, and (c) providing the structural framework for the initial phase of tissue repair $(3,7)$. Thus, the fibrin matrices that form after fracture are considered a vital component of fracture repair. Indeed, most fracture-care protocols emphasize the importance of preserving the fracture hematoma, specifically the

Authorship note: Masato Yuasa and Nicholas A. Mignemi contributed equally to this work.

Conflict of interest: G. Bhattacharjee and C. Zhao are employees of Isis Pharmaceuticals. Submitted: December 15, 2014; Accepted: June 11, 2015.

Reference information: J Clin Invest. 2015;125(8):3117-3131. doi:10.1172/JCI80313. fibrin matrix $(3,8)$. Conversely, persistent fibrin deposition or a failure of efficient fibrin clearance from wound fields due to pathologic alterations in hemostasis is detrimental to normal tissue repair (9-11). Additionally, we recently determined that persistent fibrin is a driver of pathologic bone disease (12). Thus, the contribution of fibrin to fracture repair could be both supportive and detrimental.

Over 16 million fractures are treated in the United States annually (13). Impaired fracture repair, manifesting as delayed or nonunion, which occurs in between $2.5 \%$ and $10 \%$ of these cases, (14-16) results in pain and loss of function and imposes a substantial cost burden on the health care system (13). The most common comorbidities associated with impaired fracture repair are obesity, diabetes, smoking, and advanced age (17-23). Furthermore, these comorbidities are all associated with impaired fibrin clearance or fibrinolytic activity (24-26). Given that impaired fibrinolysis is a feature common to comorbidites associated with impaired fracture repair, we hypothesize that, although extravascular fibrin matrices may exert beneficial effects on fracture repair, persistent fibrin deposition may have deleterious effects on fracture repair. In this study, we investigated whether fibrin is essential for efficient fracture repair and whether persistent fibrin matrices ultimately impede normal fracture repair.

\section{Results}

Fibrin deposition is required for efficient hemostasis following bone fracture, but is not essential for fracture repair. In order to define the 


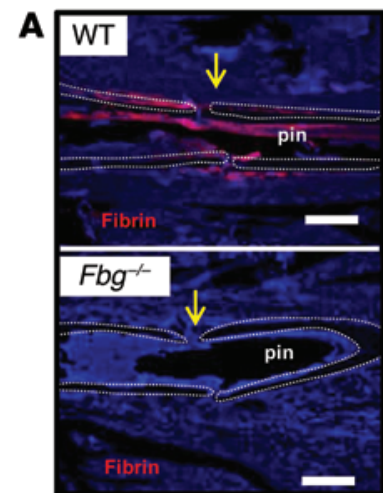

C

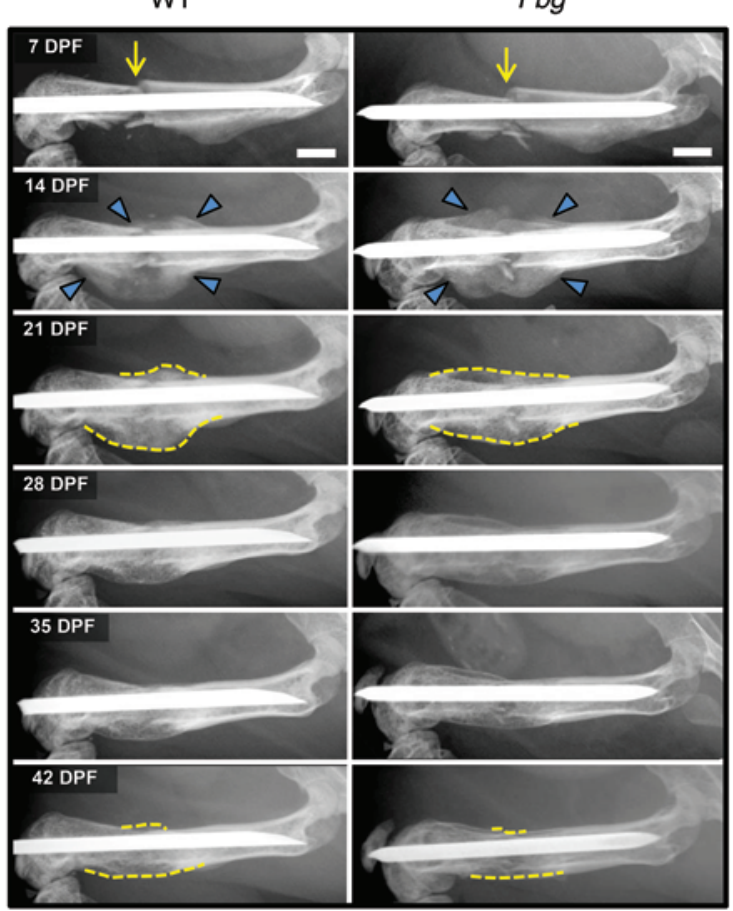

Figure 1. Fibrin is essential for limiting hemorrhage, but not for fracture callus formation. (A) Immunofluorescence-based detection of fibrin (red) at fracture site (yellow arrow) in WT and fibrinogen-deficient $\left(\mathrm{Fbg}^{-/-}\right)$mice. Note that fibrin was prominent in WT mice proximal to the fracture site (approximate location of the femora cortical bone outlined with white dotted lines), whereas fibrin was completely absent in $\mathrm{Fbg}^{-/-}$animals at 1 DPF. (B) Gross photographs of WT and $\mathrm{Fbg}^{-1-}$ mouse extremities at $1 \mathrm{DPF}$ showing local excessive bleeding and hematoma formation in $\mathrm{Fbg}^{-1-}$ mice (outlined by yellow dashes) compared with WT mice. (C) Temporal radiographic analysis of fractured femurs (yellow arrows) in WT and $\mathrm{Fbg}^{-/-}$mice. Note that the formation (blue arrowheads) of the fracture callus and macroscopic hard-tissue callus remodeling (dashed yellow lines) of the fracture callus were effectively indistinguishable in WT and $\mathrm{Fbg}^{-1}$ mice. $n \geq 10$ for each genotype. Scale bars: $1 \mathrm{~mm}$. potential roles of fibrin in fracture repair, we first characterized the temporal and spatial patterns of fibrin deposition relative to the key biologic events of fracture repair: angiogenesis and the development of a soft- and hard-tissue callus (1). Histological analyses indicated that fibrin is formed at the site of fracture shortly after injury, but is rapidly cleared during the process of intramembranous and endochondral bone formation and is no longer present at the fracture site by the time of vascular and osseous union (Figure 1A and Supplemental Figure 1; supplemental material available online with this article; doi:10.1172/JCI80313DS1). To determine whether fibrin is essential for fracture repair, we examined mice lacking fibrinogen $\left(\mathrm{Fbg}^{-/}\right)$, the precursor of fibrin, during repair of a femoral fracture. As expected, $\mathrm{Fbg}^{-/}$mice hemorrhaged excessively (Figure 1B) and no fibrin was observed at the fracture site (Figure 1A). In contrast, WT mice had no overt evidence of hemorrhage (Figure 1B) and abundant fibrin deposition was observed within the fracture site (Figure 1A). Serial radiographs of fractured femurs were performed to monitor the temporal development and subsequent remodeling of the hard-tissue callus back within the prefracture cortical bone architecture (Figure 1C). Hard-tissue callus was clearly evident proximal and distal to the fracture site in both WT and $\mathrm{Fbg}^{-/-}$mice at 14 days post fracture (DPF). During 14 to $21 \mathrm{DPF}$, the proximal and distal hard-tissue calluses converged toward the fracture site and eventually formed a bridging callus that represents the maximum size of the hard-tissue callus. Over the following 3 weeks, the hard-tissue callus condensed and became hardly discernible, approximating the original unfractured bone by $42 \mathrm{DPF}$ (Figure 1C). To determine whether the absence of fibrin affected fracture callus strength, we performed finite element analysis (FEA) using microcomputed tomography $(\mu \mathrm{CT})$ scans of the fracture site for WT and $\mathrm{Fbg}^{-/-}$mice. In this analysis, the predicted fracture callus strength did not differ between WT and $\mathrm{Fbg}^{-/-}$mice (Supplemental Figure 2). Thus, $\mathrm{Fbg}^{--}$mice show no temporal or quantitative differences in the development or subsequent remodeling of the hard-tissue callus, demonstrating that fibrin, although instrumental in limiting hemorrhage, is unnecessary for efficient fracture repair.

Given that the presence of fibrin is not required for fracture repair, we asked whether critical biological steps during fracture repair were altered in the absence of fibrin. Histological evaluation of fracture callus at 14 DPF revealed a centrally located, avascular chondroid matrix (soft-tissue callus) in both WT and $\mathrm{Fbg}^{-1-}$ mice (Figure 2A) flanked by reactive hypercellular woven bone, indicative of early bone formation during fracture repair (Figure 2B). Quantitative assessment of the soft- and hard-tissue calluses showed no significant difference between genotypes (Table 1). To determine whether fibrin is essential for vascularization of fracture callus, angiography and immunohistochemistry for CD31 were performed. Angiography of fracture calluses at 14 DPF revealed exuberant endochondral-mediated vascularization both proximal and distal to the fractures in both WT and $\mathrm{Fbg}^{-/-}$mice (Figure 2C). CD31 staining revealed numerous vessels at the interface of the hard- and soft-tissue callus in both genotypes (Figure 2C), and quantification of vascularity showed no difference in either the vascular area or the number of vessels within the facture callus of WT or $\mathrm{Fbg}^{-/-}$mice at $14 \mathrm{DPF}$ (Figure 2D). Collectively, while we 

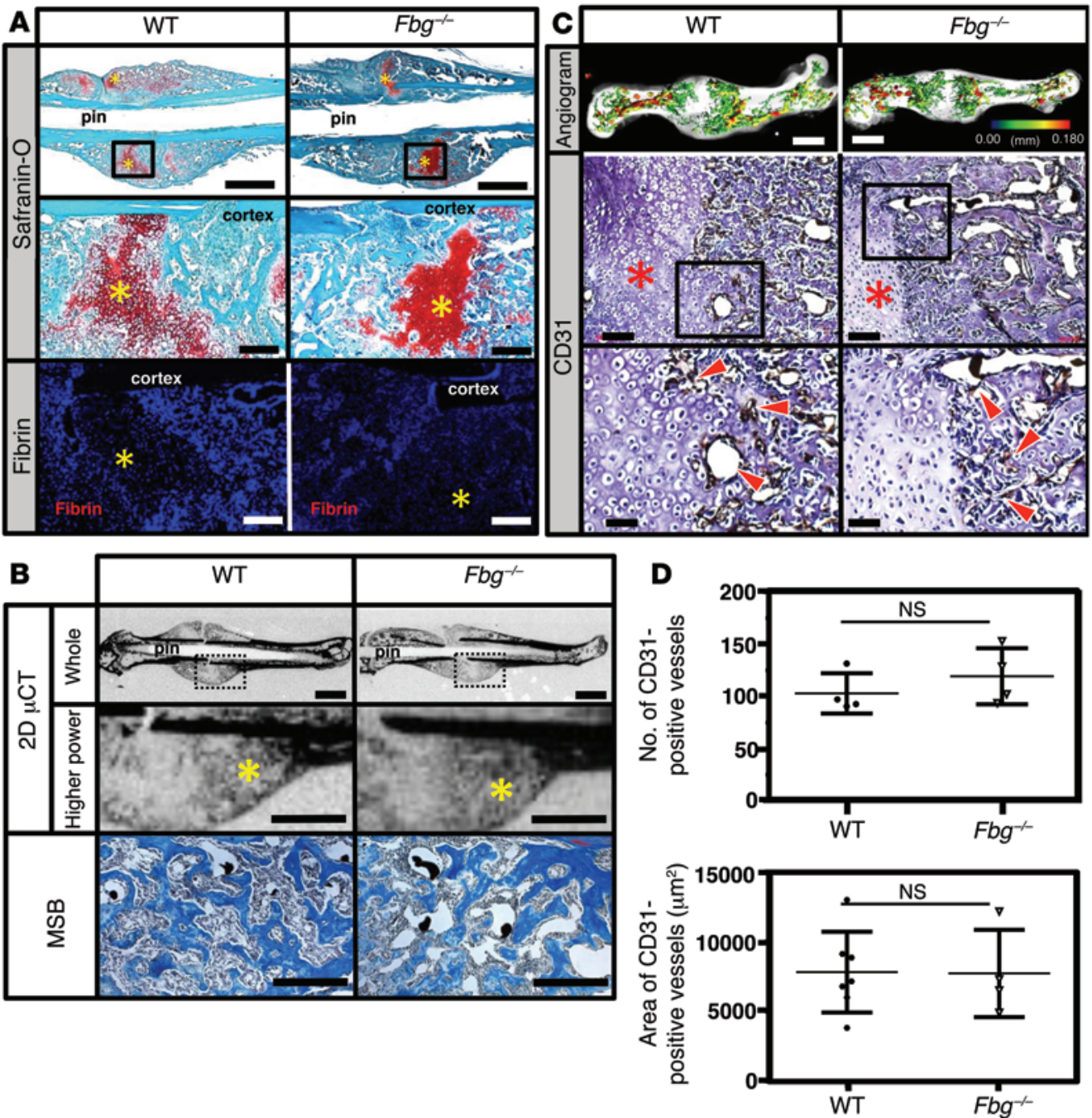

Figure 2. Fibrin is not essential for soft-tissue callus formation and vascularization of fracture callus. (A) WT and $\mathrm{Fbg}^{-/-}$mice stained with safranin $\mathrm{O}$ or immunofluorescence for fibrin at $14 \mathrm{DPF}$. Other than the distinct absence of local fibrin deposition in $\mathrm{Fbg}^{-1-}$ mice, no obvious differences were detected in fracture callus formation (chondroid soft-tissue callus, yellow asterisks). Scale bars: $1 \mathrm{~mm}$ (top panels); $100 \mu \mathrm{m}$ (middle and bottom panels). $n \geq 5$ for each genotype. (B) 2D $\mu \mathrm{CT}$ images of mineralized bone (yellow asterisks) and MSB-stained histologic sections of tissues in WT and $\mathrm{Fbg}^{-/-}$mice. Note that regardless of fibrinogen status, these areas contain reactive hypercellular trabecular woven bone. Scale bars: $1 \mathrm{~mm}$ (whole, $\mu \mathrm{CT}$ ); $500 \mu \mathrm{m}$ (higher power, $\mu \mathrm{CT}$ ); $100 \mu \mathrm{m}$ (MSB). (C) Comparative analyses of vasculature in WT and $\mathrm{Fbg}^{-1-}$ mice. Note that both $3 \mathrm{D} \mu \mathrm{CT}$ reconstructions of contrast-perfused femurs and immunofluorescence for CD31 revealed no clear differences in the macro- and microvasculature of the fracture callus at $14 \mathrm{DPF}$ in WT and $\mathrm{Fbg}^{-1-}$ mice (soft-tissue callus, red asterisks; CD31-positive vessels, red arrowheads) Scale bars: $1 \mathrm{~mm}$ (top panels); $100 \mu \mathrm{m}$ (middle panels); $50 \mu \mathrm{m}$ (bottom panels). $n \geq 4$ for each genotype. In the angiographic images, the color scale bar denotes vessel size: black $(0.00 \mathrm{~mm})$; red $(0.18 \mathrm{~mm})$. Black boxes denote areas shown at higher magnification. (D) Quantitative analysis of CD31-positive blood vessels in the callus in tissue sections. No significant differences (Student's $t$ test) were observed in the either the number (top) or total area of CD31-positive blood vessels (bottom). $n \geq 4$ for each genotype. Four sections in each sample were averaged to constitute a single replicate $(1 \mathrm{n})$. Error bars indicate SD.

cannot exclude the possibility that subtle details of the reparative process were modified by the loss of fibrin, these data demonstrate that fibrin is not required for either endochondral bone formation or vascularization of the fracture callus.

To determine whether fibrin has an effect on the union of the hard-tissue callus or subsequent fracture callus remodeling, $\mu \mathrm{CT}$ of each fracture callus at $42 \mathrm{DPF}$ was performed in WT and $\mathrm{Fbg}^{-}$ mice. Consistent with radiographic data, $3 \mathrm{D}$ and $2 \mathrm{D} \mu \mathrm{CT}$ reconstructions (Figure 3) demonstrated cortical bridging at fracture sites in both genotypes. Quantitative assessments of each fracture callus by $\mu \mathrm{CT}$ (Table 2) disclosed no significant differences in geometric properties (polar moment of inertia [pMOI]), structural properties (anisotropy), or tissue mineral density (TMD) of fracture calluses when comparing genotypes. Histological sections verified the complete transition of soft-tissue callus composed of a chondroid matrix into hard-tissue callus containing woven bone and also documented cortical bridging over the fracture site (Figure 3 and Table 1). Together, these data demonstrate that fibrin is not required for the formation of the hard-tissue callus union or the subsequent fracture callus remodeling.

Plasmin is required for fracture repair. Since fibrin was dispensable for fracture repair, we next sought to explore the hypothesis that the timely removal of a fibrin matrix is important during fracture repair. As a first direct test of this concept, we used genetargeted mice devoid of circulating plasminogen $\left(\mathrm{Plg}^{-/}\right)$, the plasmin zymogen that supports efficient degradation of the fibrin matrices. In $\mathrm{Plg}^{-1}$ mice, but not in WT mice, we observed extensive mineralization surrounding the fracture site at 7 DPF (Figure 4). At $14 \mathrm{DPF}$, the area of mineralization in $\mathrm{Plg}^{-/}$mice was much larger than in WT mice. Union of the proximal and distal hard-tissue calluses was difficult to determine radiographically because of the presence of diffuse mineralization around the fracture site. WT mice achieved hard-tissue callus union at 21 DPF that was subsequently remodeled between 21 and 42 DPF. In contrast, $\mathrm{Plg}^{-/-}$mice at $42 \mathrm{DPF}$ displayed no apparent radiographic evidence of hard-tissue callus remodeling and exhibited persistent diffuse mineralization surrounding the fracture site. The early aberrant mineralization surrounding the fracture site noted in $\mathrm{Plg}^{-}$- mice was suggestive of heterotopic ossification (Figure 4). Further analysis of the hard-tissue callus formation at the 
Table 1. Histomorphometry and radiographic analysis at 14 and 42 DPF in WT, $\mathrm{Fbg}^{-/-}, \mathrm{Plg}^{-/-}$, and $\mathrm{Plg}^{-/-} \mathrm{Fbg}^{10}$ mice

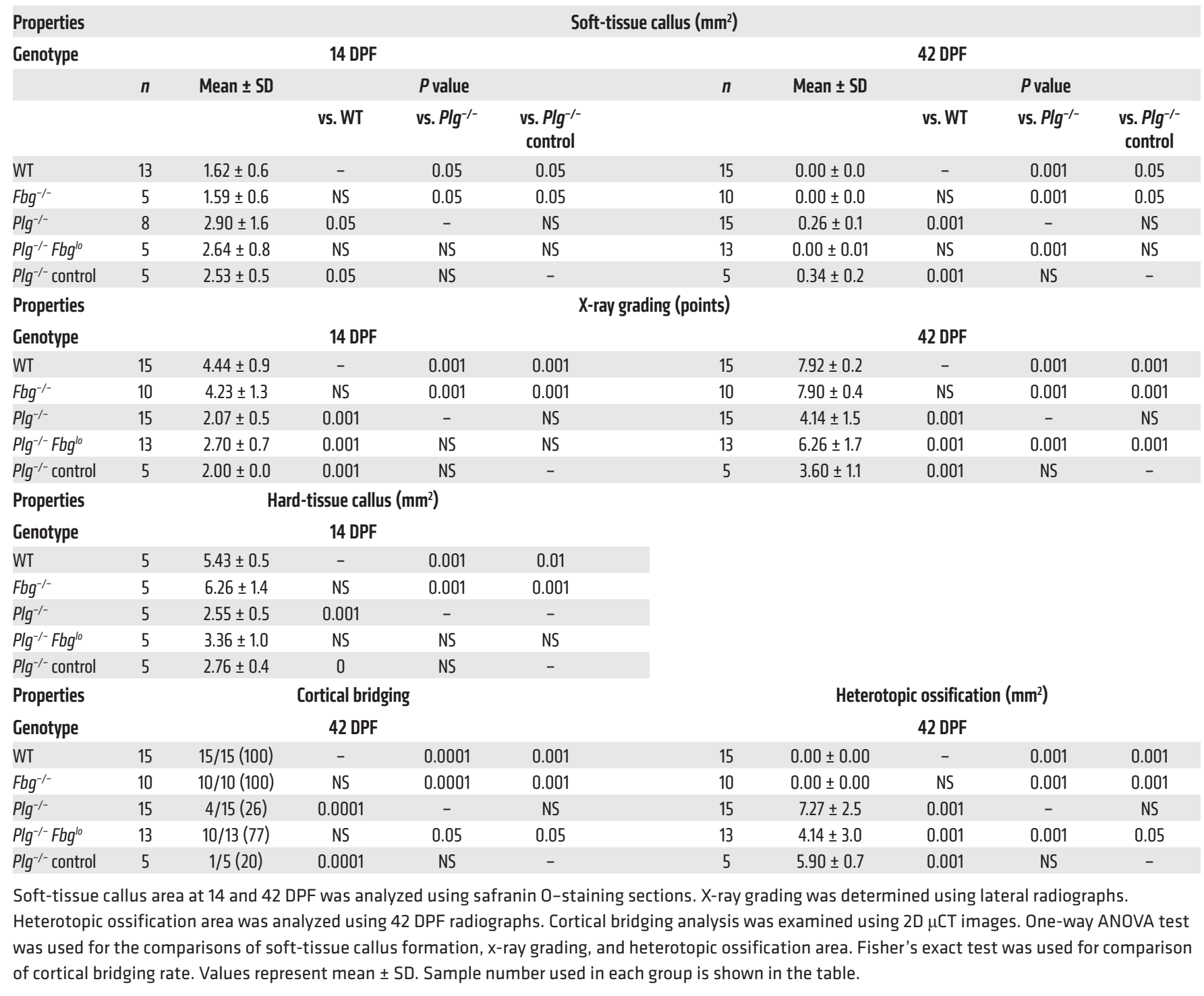

site of fracture in $\mathrm{Plg}^{-/-}$mice showed foci of mineralization within soft tissues distant from the fracture site in sagittal and axial $\mu \mathrm{CT}$ images acquired at $14 \mathrm{DPF}$ and $42 \mathrm{DPF}$ (Figure 5, A and B). von Kossa staining of tissue sections demonstrated that the soft tissue mineralization seen on $\mu \mathrm{CT}$ represents calcium deposition within skeletal muscle fibers (Figure 5C). These findings are characteristic of heterotopic ossification and suggest impaired plasmin activity as a mechanism for this pathological response to tissue injury. Therefore, loss of plasmin was associated with impaired hardtissue callus formation and heterotopic ossification.

In order to better understand the role of plasmin during fracture repair, we next examined in detail both callus formation and vascularization. Histologic examination of fracture callus at 14 DPF in $\mathrm{Plg}^{-/-}$mice revealed a large noncentrally located soft-tissue callus composed of an avascular chondroid matrix with reactive woven bone at the periphery of the fracture callus (Figure 6A). At this time, VEGF expression was observed in the hypertrophic chondrocytes contained within the chondroid matrix from both WT and $\mathrm{Plg}^{-/-}$mice, consistent with endochondral-mediated angiogenesis (Figure 6A). Abundant fibrin within the fracture callus of $\mathrm{Plg}^{-/}$mice was interposed between the separated femoral cortices and within the newly formed hard-tissue callus at the periphery of the fracture callus (Figure 6A). In contrast, WT mice exhibited no detectable fibrin at the fracture site at $14 \mathrm{DPF}$. Since endochondral hard-tissue callus formation requires vascular invasion of soft-tissue callus, we next determined whether fibrin clearance is essential for vascularization of the fracture callus. Angiograms of the fracture callus in WT mice demonstrated robust revascularization within the hard-tissue callus proximal and distal to the fracture site (Figure 6B). In contrast, $\mathrm{Plg}^{-/-}$mice showed a pronounced lack of vascularization characterized by the absence of identifiable blood vessels, as illustrated by reduced CD31 staining in the central region of the fracture site (Figure 6B) and significant reductions in both the number and total area of blood vessels 


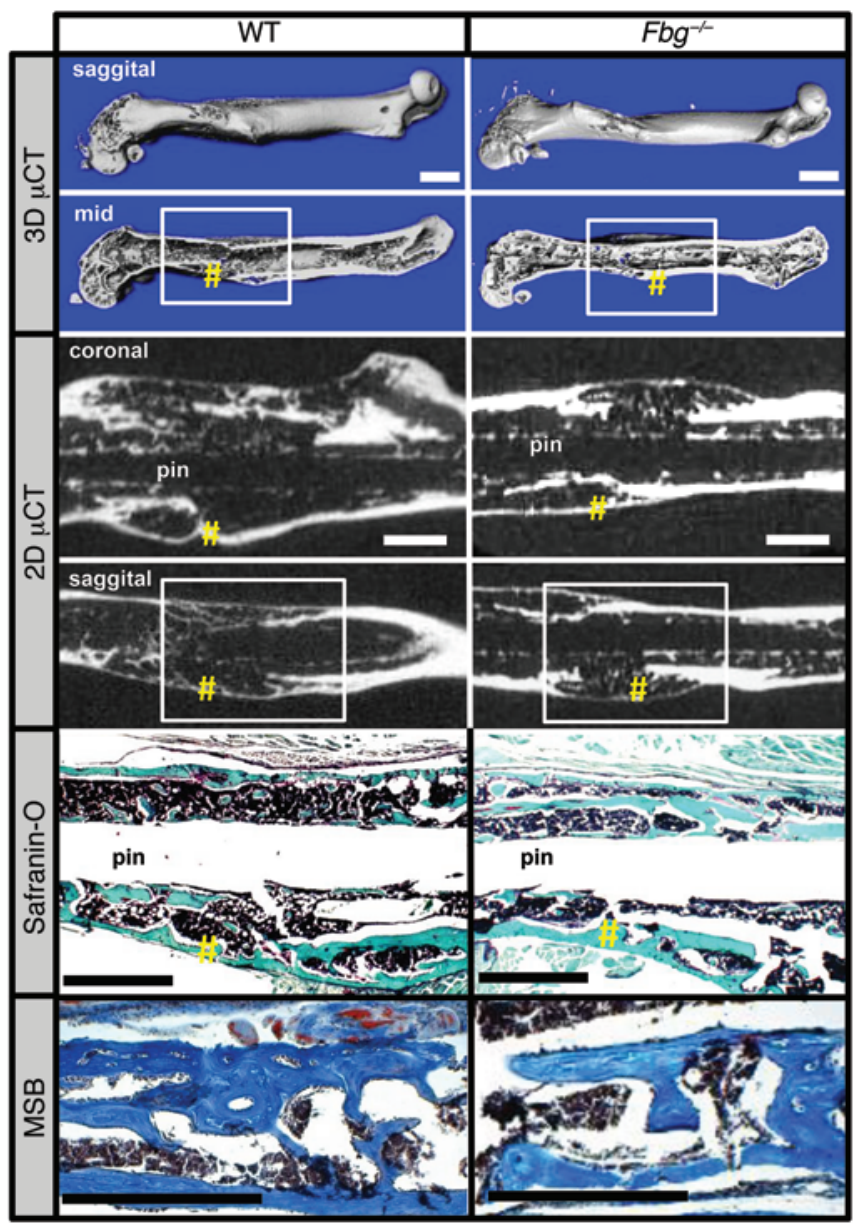

in the fracture callus (Figure 6C). These data suggest that plasmin is required for proper endochondral-mediated vascularization of the fracture callus as well as the timely conversion of the softtissue callus to newly formed woven bone.

To determine whether a plasminogen deficiency affects cortical bridging of the fracture callus and to elucidate the structure and remodeling of hard-tissue callus in the absence of plasmin, $\mu \mathrm{CT}$ was performed on $\mathrm{WT}$ and $\mathrm{Plg}^{-/-}$mice at $42 \mathrm{DPF}$. Consistent with radiologic data, representative images of $3 \mathrm{D} \mu \mathrm{CT}$ reconstructions of a fractured femur from $\mathrm{Plg}^{-/-}$mice showed a markedly disorganized fracture callus (Figure 7). In addition, while $2 \mathrm{D} \mu \mathrm{CT}$ reconstructions of fracture sites in WT mice showed evidence of cortical bridging over the fracture site, the hard-tissue callus in $\mathrm{Plg}^{-/-}$mice failed to unite across the fracture site (Figure 7 and Table 1). This failure to unite was associated with an absence of remodeling of the hard-tissue callus back to the original femoral cortical contour in $\mathrm{Plg}^{-/}$mice. Quantitative evaluations of fracture callus by $\mu \mathrm{CT}$ at $42 \mathrm{DPF}$ demonstrated that $\mathrm{Plg}^{-/-}$mice show alterations in composition and structure including elevated pMOI, bone volume, and bone area (Table 2). Together, these data independently validate radiograph evidence suggesting impaired callus formation and remodeling in $\mathrm{Plg}^{-/-}$mice. Histological examination of the newly formed bone in the fracture callus by martius scarlet blue (MSB) staining revealed no morphologic differences in bone formation between $\mathrm{WT}$ and $\mathrm{Plg}^{-/-}$mice. Furthermore, examination of the fracture gap in $\mathrm{Plg}^{-/-}$mice by saf-
Figure 3. Fibrin is not essential for hard-tissue callus union. Top panels show $3 \mathrm{D} \mu \mathrm{CT}$ reconstructions of femurs from WT and $\mathrm{Fbg}^{-1-}$ mice at $42 \mathrm{DPF}$ Note there are no clear structural differences in animals of each genotype (white boxes denote site of fracture; yellow pound symbols denote areas of cortical bridging). Middle panels show coronal and sagittal 2D $\mu \mathrm{CT}$ images, further demonstrating cortical bridging by hard-tissue callus in both WT and $\mathrm{Fbg}^{-/-}$mice (yellow pound symbols). Bottom panels show safranin 0 and MSB staining establishing cortical bone union in both WT and $\mathrm{Fbg}^{-1}$ mice (yellow pound symbols). $n \geq 10$ for each genotype. Scale bars: $1 \mathrm{~mm}$.

ranin O staining confirmed absence of cortical bridging and persistent soft-tissue callus surrounding a central area of fibrosis at the fracture site. These data demonstrate that, although bone formation is histomorphologically normal, there is a delay in replacing the avascular soft-tissue callus with vascularized hard-tissue callus in $\mathrm{Plg}^{-/-}$mice (Figure 7). Immunohistochemistry revealed that fibrin was centrally located over the fracture site and within the area of fibrosis opposing the ends of the fracture callus (Figure 7). Together, these data confirm that plasmin is essential for the removal of fibrin from the fracture callus and endochondralmediated vascularization of the fracture callus as well as the appropriate formation and union of new bone at the fracture site.

Knock down of the fibrin precursor, fibrinogen, restores fracture repair and limits heterotopic ossification in plasminogen-deficient mice. Since both plasminogen and plasmin have biologic functions other than fibrin removal, we next determined whether a failure to remove fibrin was responsible for impaired fracture repair and heterotopic ossification. Here, circulating fibrinogen levels were reduced in $\mathrm{Plg}^{-/}$mice using an antisense oligonucleotide (ASO), gapmer, designed to selectively impede hepatic fibrinogen protein production (Supplemental Figure 3). Studies using these $\mathrm{Plg}^{-/-} \mathrm{Fbg}^{l o}$ cohorts were controlled with $\mathrm{Plg}^{-/-}$mice treated with a nonsense ASO of similar structure, resulting in $\mathrm{Plg}^{-/-}$control cohorts. Following fracture, $\mu \mathrm{CT}$ was performed to define the structure of the hard-tissue callus and determine fracture callus union in $\mathrm{Plg}^{-/-}$ Fbg ${ }^{l o}$ mice at $42 \mathrm{DPF}$. 3D $\mu \mathrm{CT}$ reconstructions demonstrated a more organized hard-tissue callus (Figure 8, 3D $\mu \mathrm{CT}$ ) in $\mathrm{Plg}^{-/-} \mathrm{Fbg}^{l o}$ mice compared with $\mathrm{Plg}^{-/-}$control mice. As an extension of this work, $2 \mathrm{D} \mu \mathrm{CT}$ reconstructions were done to better define cortical bridging of the fracture site by the hard-tissue callus. In contrast to $\mathrm{Plg}^{-/-}$control mice, which fail to form a complete hard-tissue callus bridge over the fracture gap by $42 \mathrm{DPF}$ (Figure 8, 2D $\mu \mathrm{CT}$ ), the gap in most $\mathrm{Plg}^{--} \mathrm{Fbg}^{l o}$ mice (10 of 13 mice, Table 1) was found to be overlaid with a well-formed hard-tissue callus (Figure 8, 2D $\mu \mathrm{CT}$ ). Histological sections and histomorphometric analysis also demonstrated more organized and mature-appearing fracture calluses (as evidenced by the presence of reactive woven bone in the fracture callus, a lack of residual soft-tissue callus, and robust cortical bridging) in $\mathrm{Plg}^{-/-} \mathrm{Fbg}^{l o}$ mice relative to $\mathrm{Plg}^{-/-}$control mice (Figure 8 and Table 1). Quantitative $\mu \mathrm{CT}$ evaluation confirmed that the fracture calluses of $\mathrm{Plg}^{-/} \mathrm{Fbg}^{l o}$ mice had significantly improved geometric and structural properties compared with those of $\mathrm{Plg}^{-1}$ control mice (Table 2). In contrast to $\mathrm{Plg}^{-/-}$control mice, $\mathrm{Plg}^{-/-} \mathrm{Fbg}^{\mathrm{lo}}$ mice showed significant increases in TMD and decreases in bone volume, bone area, and pMOI, all indicative of a well-formed, remodeled callus (Table 2). To confirm that the ASO-mediated fibrinogen knockdown was successful in preventing fibrin deposition within the fracture callus, we histologically investigated for 
Table 2. Bone properties of fractured femur at 42 DPF were analyzed using Scanco Medical $\mu \mathrm{CT}$ software

\begin{tabular}{|c|c|c|c|c|c|c|c|c|c|c|}
\hline Properties & \multicolumn{5}{|c|}{$\mathrm{pMO}\left(\mathrm{mm}^{4}\right)$} & \multicolumn{5}{|c|}{ Tb. TMD (mg HA/cm³) } \\
\hline \multirow[t]{2}{*}{ Genotype } & \multirow[b]{2}{*}{$n$} & \multicolumn{3}{|c|}{$42 \mathrm{DPF}$} & & \multicolumn{5}{|c|}{$42 \mathrm{DPF}$} \\
\hline & & Mean \pm SD & \multicolumn{3}{|c|}{$P$ value } & $n$ & Mean \pm SD & \multicolumn{3}{|c|}{$P$ value } \\
\hline WT & 13 & $0.77 \pm 0.30$ & - & 0.001 & 0.001 & 13 & $1075 \pm 38$ & - & 0.001 & 0.001 \\
\hline $\mathrm{Fbg}^{-/-}$ & 9 & $0.77 \pm 0.19$ & NS & 0.001 & 0.001 & 9 & $1044 \pm 25$ & NS & 0.001 & 0.05 \\
\hline $\mathrm{Plg}^{-/-}$control & 4 & $2.31 \pm 0.94$ & 0.001 & NS & - & 4 & $972 \pm 41$ & 0.001 & NS & - \\
\hline Properties & \multicolumn{5}{|c|}{ Bone volume $\left(\mathrm{mm}^{3}\right)$} & \multicolumn{5}{|c|}{ Degree of anisotropy } \\
\hline Genotype & \multicolumn{4}{|c|}{$42 \mathrm{DPF}$} & & \multicolumn{5}{|c|}{$42 \mathrm{DPF}$} \\
\hline WT & 13 & $4.02 \pm 0.81$ & - & 0.001 & 0.001 & 13 & $2.32 \pm 0.41$ & - & 0.001 & 0.001 \\
\hline $\mathrm{Fbg}^{-/-}$ & 9 & $4.20 \pm 1.07$ & NS & 0.001 & 0.001 & 9 & $2.28 \pm 0.31$ & NS & 0.001 & 0.01 \\
\hline Properties & \multicolumn{5}{|c|}{ Bone area $\left(\mathrm{mm}^{2}\right)$} & & & & & \\
\hline Genotype & \multicolumn{5}{|c|}{$42 \mathrm{DPF}$} & & & & & \\
\hline WT & 13 & $1.01 \pm 0.20$ & - & 0.001 & 0.001 & & & & & \\
\hline $\mathrm{Fbg}^{-/-}$ & 9 & $1.05 \pm 0.27$ & NS & 0.001 & 0.001 & & & & & \\
\hline $\mathrm{Plg}^{-/-}$ & 14 & $1.59 \pm 0.23$ & 0.001 & - & NS & & & & & \\
\hline $\mathrm{Plg}^{-1-} \mathrm{Fbg}^{10}$ & 10 & $1.22 \pm 0.35$ & NS & 0.01 & 0.01 & & & & & \\
\hline $\mathrm{Plg}^{-/-}$control & 4 & $1.77 \pm 0.34$ & 0.001 & NS & - & & & & & \\
\hline
\end{tabular}

the presence of fibrin at the fracture site (Figure 8). Immunostaining confirmed a marked reduction in fibrin deposition in the fracture callus and within the intramedullary space of $\mathrm{Plg}^{-/-} \mathrm{Fbg}^{l o}$ mice as compared with $\mathrm{Plg}^{-/-}$control mice.

As pharmacological fibrinogen suppression rescued cortical bridging at $42 \mathrm{DPF}$, we next examined the fracture callus at an earlier time (14 DPF), when both the soft-tissue and hard-tissue callus were present for better assessment of fracture repair. Histologic evaluation of fracture callus in $\mathrm{Plg}^{-/-} \mathrm{Fbg}^{l o}$ mice at $14 \mathrm{DPF}$ revealed a wellformed and organized soft-tissue callus flanked by hard-tissue callus that was similar to that seen in WT mice (Figure 9A). In contrast, the soft-tissue callus in $\mathrm{Plg}^{-/-}$mice was poorly formed and disorganized. Immunofluorescence staining for fibrin at $14 \mathrm{DPF}$ confirmed persistent fibrin at the fracture site in $\mathrm{Plg}^{-/-}$mice, but a marked reduction of fibrin was observed in $\mathrm{Plg}^{-/} \mathrm{Fbg}^{l o}$ mice (Figure 9, A and B). Fracture sites were examined for CD31 immunostaining to determine whether fibrinogen knockdown resulted in increased vascularity of the fracture callus. Increased numbers of CD31-positive cells and the percentage of total tissue area defined by CD31-positive vessels at the periphery of the fracture callus were noted (Figure 9, A and C). These data demonstrate that impaired fibrinolysis results in persistent fibrin, which compromises soft-tissue callus formation and the normal vascularization of the fracture callus in $\mathrm{Plg}^{-/-}$mice.

Fibrin deposits at the interface between the avascular soft-tissue callus and the vascularized hard-tissue callus. Since $\mathrm{Plg}^{-1-}$ mice had a persistent fibrin matrix associated with both impaired bone for- mation and vascularization, we next determined whether fibrin is present at the interface of the avascular soft-tissue callus and vascularized hard-tissue callus (Figure 10), where it might serve as a barrier to cell migration. We observed angiogram contrast material at the interface between soft- and hard-tissue callus indicative of chondrocyte-mediated recruitment of vascularity, which supports transport of mesenchymal progenitors and newly forming bone into the soft-tissue callus. Consistent with previous findings (1, 27), CD31 immunostaining revealed endothelial cells surrounding patent vessels located at the leading edge of the hard-tissue callus (Figure 10). Immunohistochemistry for fibrin performed on serial sections show fibrin deposits interposed between the soft- and hard-tissue callus and surrounding patent vessels. Fibrin localized near the sites of active vascularization, suggesting that persistent fibrin deposition at these sites may impede the remodeling of the soft-tissue callus into a vascularized hard-tissue callus (Figure 10). Overall, these data support the concept that persistent fibrin may act as a physical barrier to revascularization during endochrondral ossification, thereby inhibiting the replacement of soft-tissue callus with hard-tissue callus.

\section{Discussion}

These studies reveal the unanticipated finding that local deposition of the coagulation provisional matrix protein, fibrin, is not essential for fracture repair. The findings fundamentally revise the long-standing and prevailing view that, during fracture repair, 


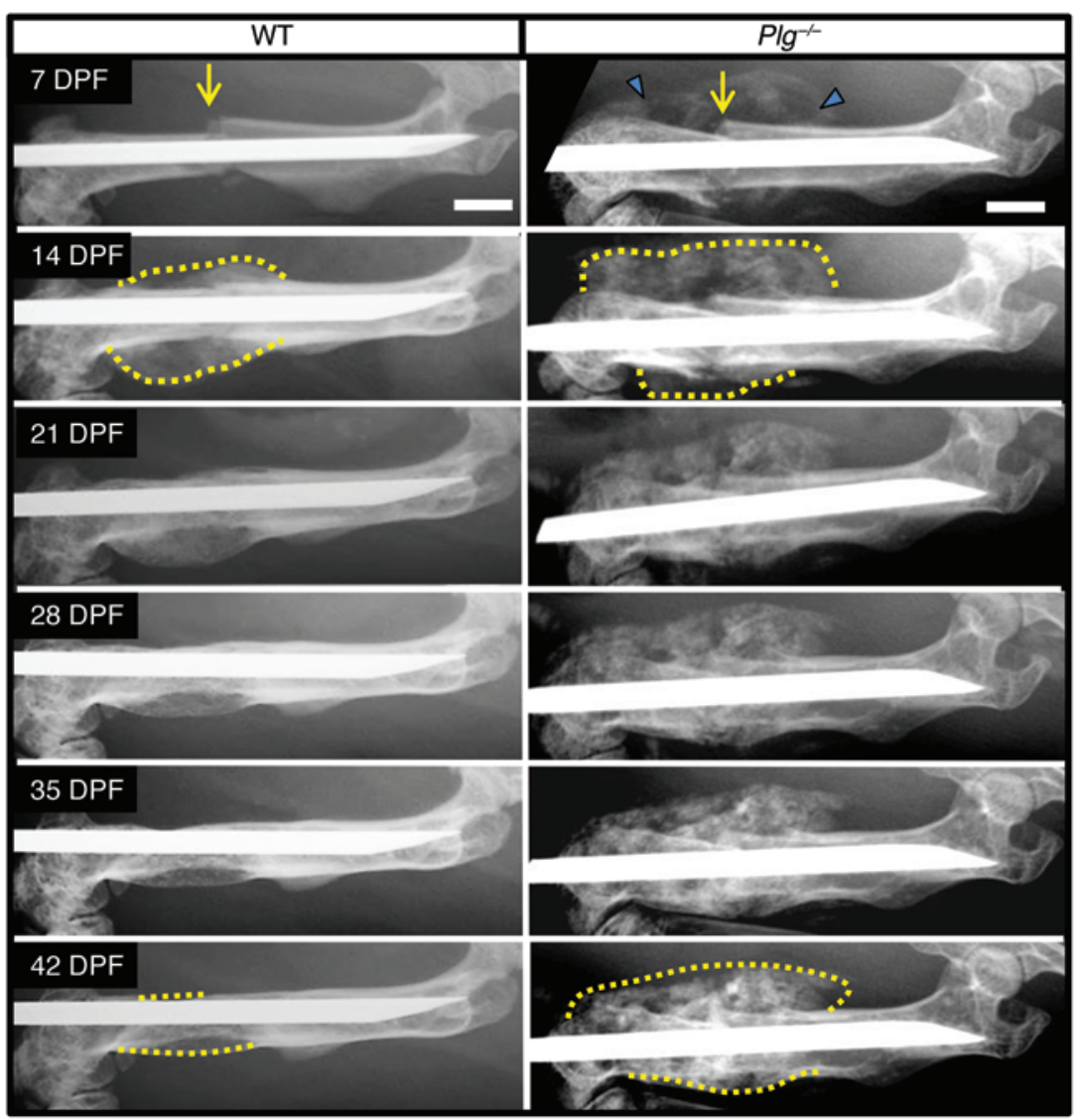

Figure 4. Plasminogen-deficient mice show abnormal hard-tissue callus formation. Serial radiographic analysis of fractured femurs (yellow arrows) revealing marked differences in the formation (blue arrowheads) and macroscopic remodeling of the hard-tissue fracture callus (dashed yellow lines) in WT and $\mathrm{Plg}^{-1-}$ mice. Note that relative to WT mice, the fracture callus in $\mathrm{Plg}^{-/-}$mice was hypertrophic and failed to undergo remodeling of the macroscopic hard-tissue callus over the first 6 weeks after fracture. In addition, both appreciable and persistent soft-tissue mineralization were noted adjacent to the injury site (blue triangles). Representative images of $n=15$ for each genotype; see Table 1 and Supplemental Figure 4 for quantification. Scale bars: $1 \mathrm{~mm}$. fibrin matrices serve as the initial scaffolds for healing damaged bone and are instrumental for local inflammatory processes, neovascularization, and mesenchymal progenitor cell migration into damaged bone. While the presence of multiple integrin- and nonintegrin-binding motifs capable of promoting cellular migration on fibrin strongly favors the notion that fibrin is critical to fracture repair (28), our data refute the current paradigm. The present studies clearly demonstrate that fibrin is not essential for fracture repair in mice, since we did not observe any detectable change in the outcome of fracture repair in the absence of fibrin. Of course, consistent with the contribution of fibrin to hemostasis, the availability of fibrin(ogen) did limit local hemorrhage within the injured zone following long-bone fracture. Nonetheless, fibrin matrices do not appear to be strictly required for the mesenchymal cell recruitment, activation, and differentiation events or other physiological processes essential for efficient bone repair. Perhaps even more provocatively, the present studies show that instead, timely and efficient removal of fibrin is essential for fracture repair. Plasminmediated clearance of fibrin is vital for the vascularization of the soft-tissue callus and subsequent formation and remodeling of the hard-tissue callus. Our results direct a reevaluation of the role of fibrin in fracture repair.

Persistent fibrin deposition at the fracture site impedes fracture healing and is counterproductive to bone repair through multiple potential mechanisms. Given that angiogenesis is requisite for osteoblast-mediated matrix mineralization during fracture repair $(27,29-33)$ and that vascular dysfunction and hypofibrinolysis are common to many comorbid conditions associated with delayed fracture repair (17-20, 23, 34-38), we postulated that impaired fracture repair in $\mathrm{Plg}^{-/-}$mice is the result of impaired angiogenesis. Just as in the growth plate, endochondral angiogenesis in fracture repair is regulated by hypertrophic chondrocytes that release VEGF-A, calcium, and phosphate, which direct endothelial and osteoprogenitor cells to form new blood vessels and bone. Hypofibrinolysis in the absence of plasmin(ogen) did not affect development of chondroid soft-tissue callus or expression of VEGF-A in hypertrophic chondrocytes, but instead resulted in persistent fibrin deposition at the interface between hypertrophic chondrocytes in soft-tissue callus and invading endothelial and osteoblastic cells in the leading edge of the hard-tissue callus. The specific location of fibrin deposition and the paucity of extramedullary vasculature that typically develops from the shunting of blood flow from the intramedullary vasculature after fracture (1) support the notion that persistent fibrin deposition represents a physical barrier that prevents cellular trafficking and tissue reorganization. Indeed, such a mechanism is strongly supported by our finding that reducing fibrinogen prior to fracture in plasminogen-deficient mice partially rescues endochondral angiogenesis and fracture union. Thus, these studies highlight the strict requirement for plasmin-mediated fibrinolysis for the recruitment of endothelial and osteoblast precursors by hypertrophic chondrocytes, thereby inhibiting endochondral angiogenesis and ossification.

Importantly, reducing plasma fibrinogen levels, and secondarily fibrin deposition, substantially rescues defective fracture repair in plasminogen-deficient animals. Effective depletion of fibrinogen by ASO treatment was confirmed by the absence of detectable fibrino- 
B
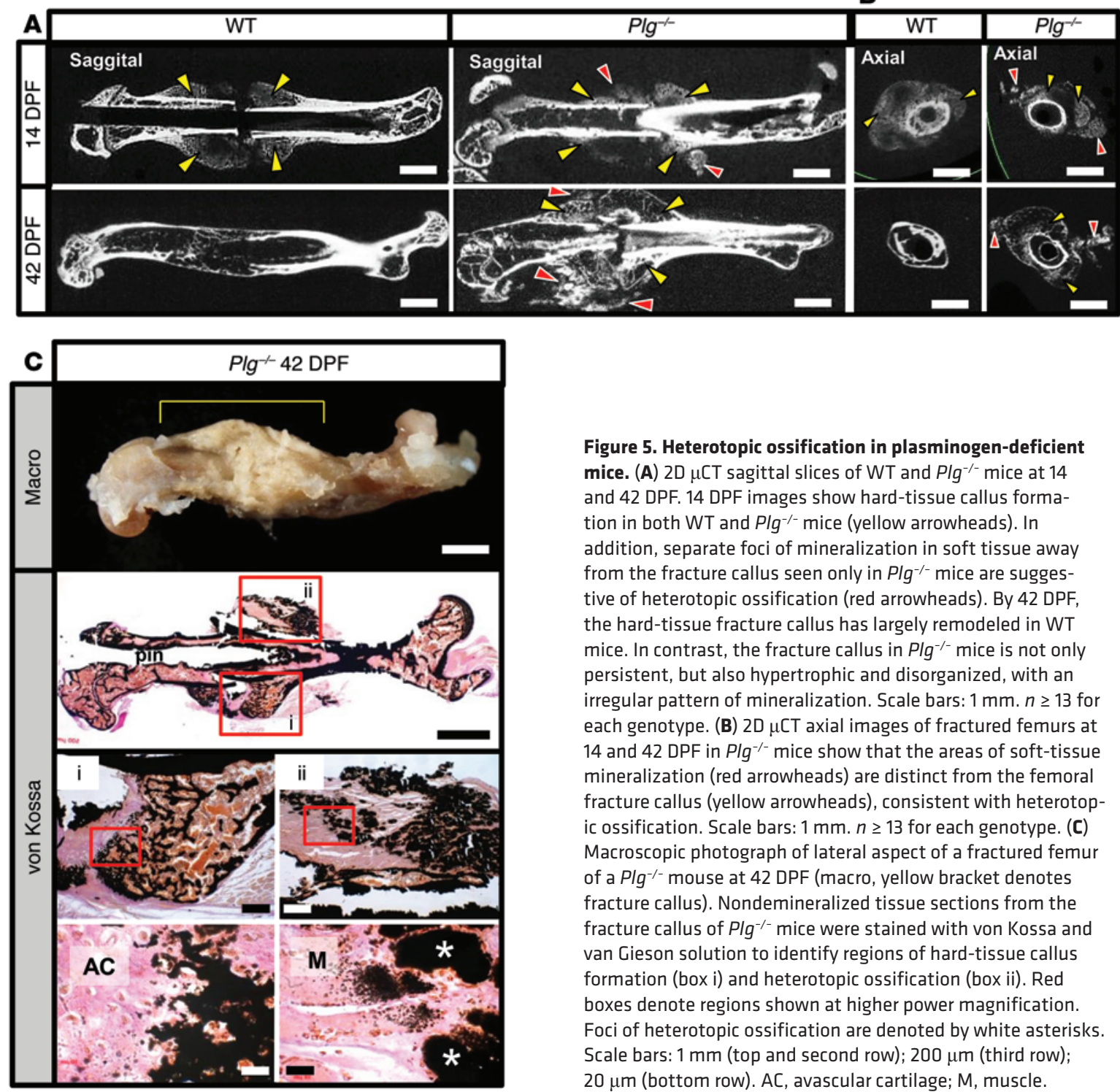

Figure 5. Heterotopic ossification in plasminogen-deficient mice. (A) $2 \mathrm{D} \mu \mathrm{CT}$ sagittal slices of WT and $\mathrm{Plg}^{-/-}$mice at 14 and 42 DPF. 14 DPF images show hard-tissue callus formation in both WT and $\mathrm{Plg}^{-1-}$ mice (yellow arrowheads). In addition, separate foci of mineralization in soft tissue away from the fracture callus seen only in $\mathrm{Plg}^{-/-}$mice are suggestive of heterotopic ossification (red arrowheads). By 42 DPF, the hard-tissue fracture callus has largely remodeled in WT mice. In contrast, the fracture callus in $\mathrm{Plg}^{-/-}$mice is not only persistent, but also hypertrophic and disorganized, with an irregular pattern of mineralization. Scale bars: $1 \mathrm{~mm}$. $n \geq 13$ for each genotype. (B) $2 \mathrm{D} \mu \mathrm{CT}$ axial images of fractured femurs at 14 and $42 \mathrm{DPF}$ in $\mathrm{Plg}^{-/-}$mice show that the areas of soft-tissue mineralization (red arrowheads) are distinct from the femoral fracture callus (yellow arrowheads), consistent with heterotopic ossification. Scale bars: $1 \mathrm{~mm}$. $n \geq 13$ for each genotype. (C) Macroscopic photograph of lateral aspect of a fractured femur of a $\mathrm{Plg}^{-1-}$ mouse at $42 \mathrm{DPF}$ (macro, yellow bracket denotes fracture callus). Nondemineralized tissue sections from the fracture callus of $\mathrm{Plg}^{-1-}$ mice were stained with von Kossa and van Gieson solution to identify regions of hard-tissue callus formation (box i) and heterotopic ossification (box ii). Red boxes denote regions shown at higher power magnification. Foci of heterotopic ossification are denoted by white asterisks. Scale bars: $1 \mathrm{~mm}$ (top and second row); $200 \mu \mathrm{m}$ (third row); $20 \mu \mathrm{m}$ (bottom row). AC, avascular cartilage; M, muscle.

gen levels in plasma and significant $(P=0.0015)$ reduction in fibrin deposition within fracture callus. Although fibrinogen ASOs are a convenient and effective method of reducing fibrinogen expression in controlled experimental settings, several factors should be considered before contemplating their clinical utility. Because the half-life of circulating fibrinogen is relatively long (39) ( $~ 5$ days) and fibrin is deposited immediately after injury, ASO-based interventions would likely be more applicable for elective surgeries than for trauma. However, because fibrin deposition may be relatively dynamic, intervention with ASOs may also have therapeutic utility in trauma settings. Alternate clinical applications of our findings might include enhancing fibrinolytic activity to improve the incidence of successful fracture repair. Future investigations are required to determine the clinical efficacy of fibrinogen ASOs or alternative methods designed to promote fibrinolysis on bone regeneration after either trauma or elective orthopedic surgical procedures.

The incomplete rescue of fracture repair following ASO-mediated fibrinogen depletion may be due to residual fibrin or function of plasminogen independent of fibrinolysis activity. While the prin- cipal role of plasmin in fracture repair appears to be fibrin clearance in support of efficient fracture callus neovascularization and bone formation, our studies do not formally exclude that plasmin also supports the infiltration of monocytes and macrophages (40) that phagocytose necrotic debris from the site of injury and inhibit the acute inflammatory response (41). Thus, plasmin deficiency may subtly prolong the necroinflammatory phase of fracture repair independently of fibrin degradation. Plasmin activity also has been proposed to support the release of growth factors important for wound repair, such as TGF- $\beta(42,43)$ and VEGF $(44)$. Finally, plasmin may have direct effects on the osteoblast within the fracture callus. Inhibition of plasmin delays mineralization and differentiation of in vitro osteoblast cultures grown in the absence of fibrin (45), suggesting that plasmin may directly promote maturation of osteoblast precursors to mature osteoblasts during fracture repair. Interestingly, Kawao et al. proposed that bone repair is largely independent of plasminogen-mediated fibrinolytic activity (46). The seeming contradiction with the present findings could be due to differences in the bone-injury model employed (a drill hole bone defect) or dif- 

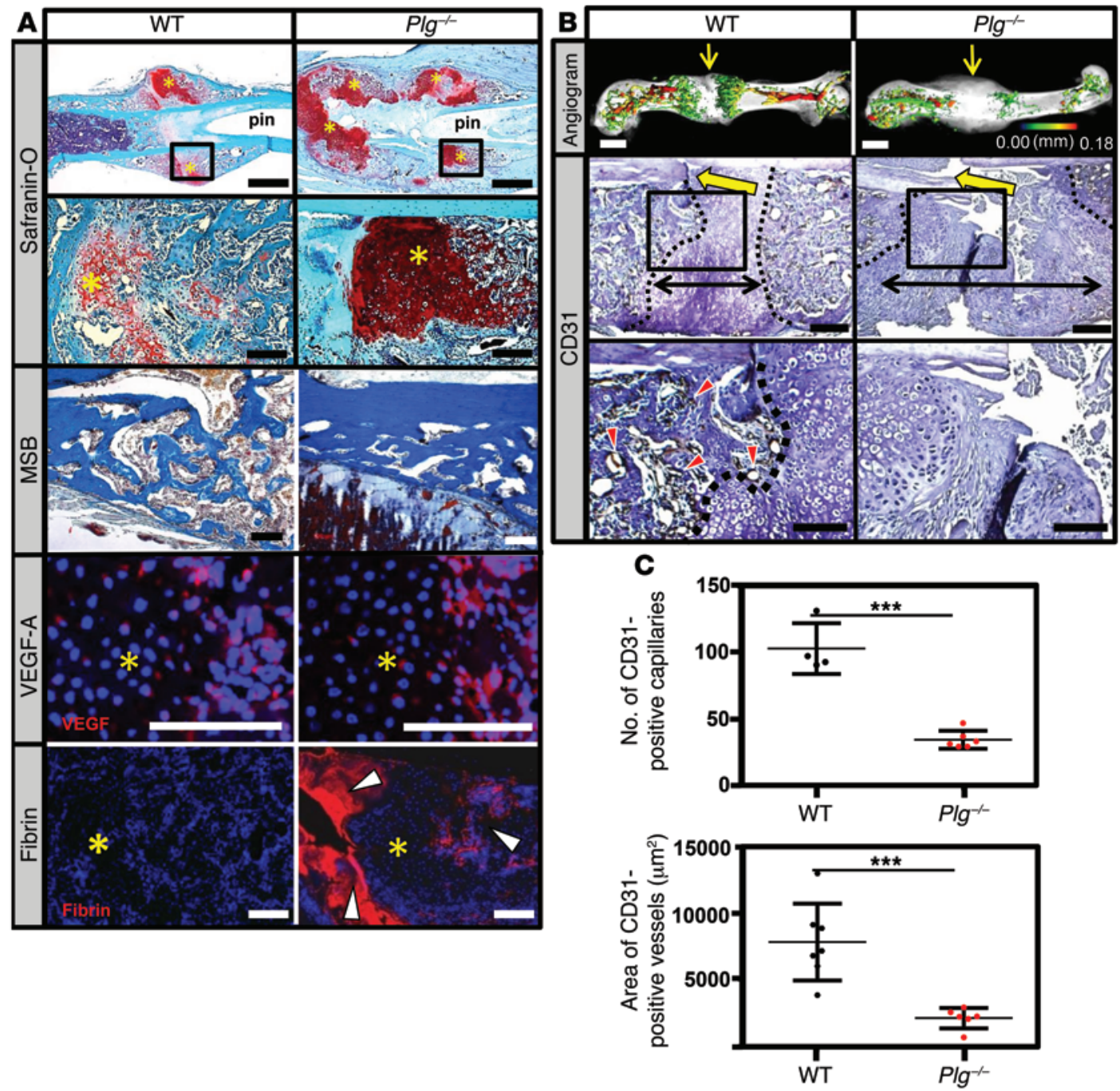

Figure 6. Plasmin is not required for soft-tissue callus formation, but is essential for vascularization of fracture callus. (A) Safranin O- and MSB-stained sections and immunofluorescence for VEGF-A and fibrin in the fracture callus at 14 DPF. Safranin 0 staining reveals the presence of the soft-tissue callus, while MSB-stained sections demonstrate that, while reduced in quantity compared with WT mice, the newly formed bone is histologically indistinguishable from newly formed bone in WT mice. VEGF immunofluorescence staining reveals VEGF expression within the hypertrophic chondrocytes (avascular soft-tissue callus, yellow asterisks) of WT and $\mathrm{Plg}^{-/-}$mice. Fibrin immunofluorescence reveals excessive fibrin deposition (white arrowheads) at the fracture site and in the hard-tissue callus of $\mathrm{Plg}^{-/-}$mice at $14 \mathrm{DPF}$ compared with WT mice. Scale bars: $1 \mathrm{~mm}$ (top row); $100 \mu \mathrm{m}$ (second, third, and fourth rows). (B) Representative 3D $\mu \mathrm{CT}$ reconstructions of angiogram contrast-perfused femurs show reduced revascularization of the fracture callus in $\mathrm{Plg}^{-/-}$mice at $14 \mathrm{DPF}$ (color scale bar indicates vessel size range: black $=0.00 \mathrm{~mm}$, red $=0.18 \mathrm{~mm}$ ). Immunohistochemistry for CD31-positive vessels (red arrowheads) in the fracture site (yellow arrows). The interface of avascular soft-tissue callus and vascularized hard-tissue callus is marked by a black dashed line. The fracture gap is defined as the region between hard-tissue calluses (black double arrows). Scale bars: $1 \mathrm{~mm}$ (top row); $100 \mu \mathrm{m}$ (middle and bottom rows). (C) Statistical analysis (Student's $t$ test) comparing number (top) and total area (bottom) of CD31-positive blood vessels in the callus. Four sections in each sample were averaged to constitute a single replicate $(1 n) .{ }^{* *} P<0.01$. Error bars represent SD. $n \geq 4$ for each genotype.

ferences in the methods and/or effectiveness of reducing circulating fibrinogen levels. While future studies are required to further explore nonfibrinolytic roles of plasmin during fracture repair, our data indicate that plasmin activity is, at least in part, essential for fracture repair, acting by supporting fibrin clearance.

Following development of hard-tissue callus, remodeling the callus to the original macroscopic architecture of the prefracture bone was also substantially delayed in the absence of plasminogen. The remodeling of newly formed bone in fracture callus becomes clinically apparent after osseous union across the fracture site (1). Thus, it is plausible that loss of plasminogen activity affects osteoclastogenesis, osteoclast function, and/or osteoclast/osteoblast interactions. In support of this, plasminogen and its principle activators (urokinase-type plasminogen activator [uPA]/tissue-type plasminogen activator [tPA]) have been reported to activate multiple elements of bone remodeling $(47,48)$. However, depletion of fibrinogen partially rescued fracture union and remodeling in the setting of a complete deficiency of plasminogen, indicating that, although plasmin and its activators are capable of driving the bone remodeling process, plasminogen is not essential for bone remodeling associated with fracture repair. Instead, these data potentially implicate fibrin as a negative regulator of bone remodeling. However, preliminary analyses suggest that similar numbers of osteoclasts surrounded newly formed woven bone spicules follow- 


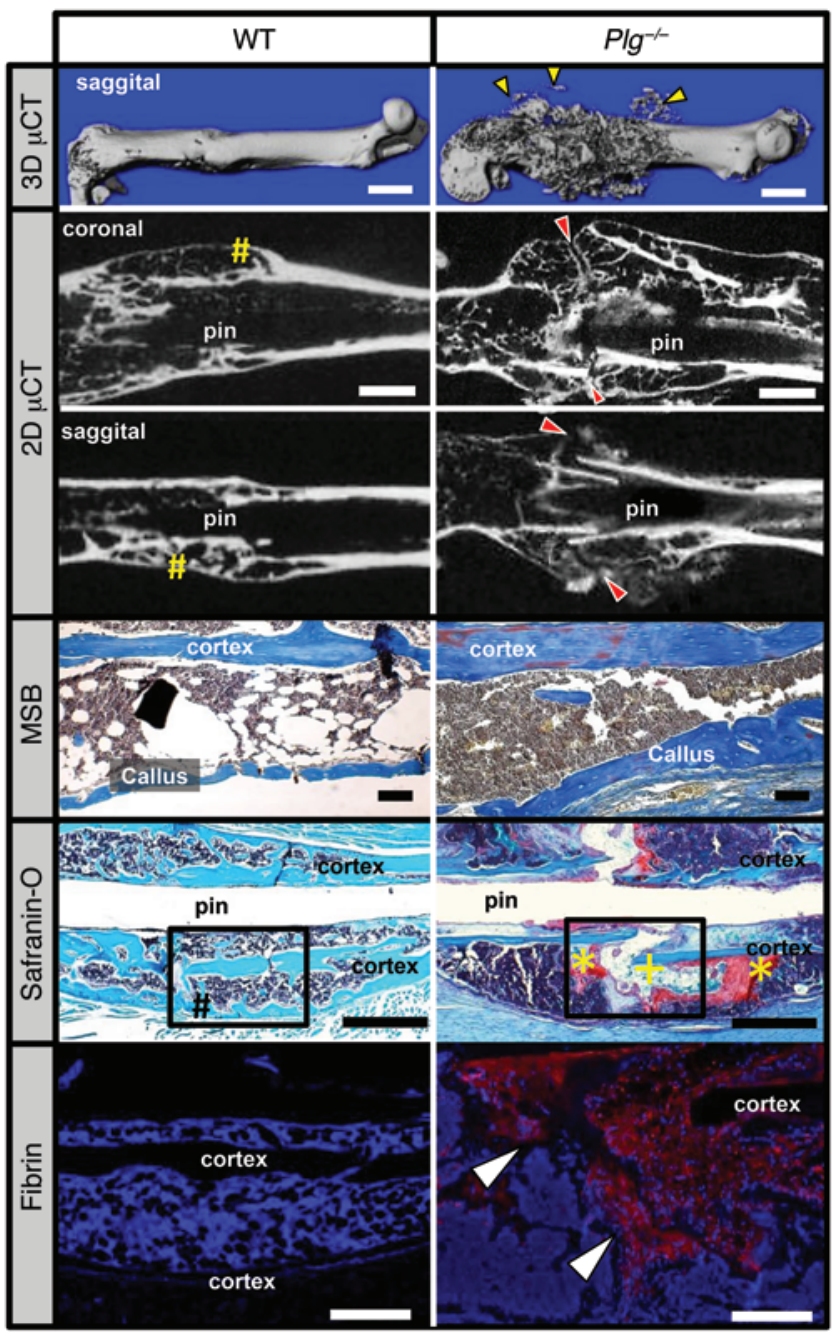

ing fracture in all genotypes analyzed (not shown). Additionally, in studies previously reported, local fibrin deposition within bone tissue was found to directly stimulate osteoclastogenesis through engagement of CD11b/CD18 on monocytes, thereby inducing severe osteoporosis (12). Thus, it is postulated that the persistent presence of fibrin, if anything, likely drives increased osteoclastogenesis during fracture repair. As an alternative, the most straightforward explanation of delayed callus remodeling in the absence of plasminogen is the delay in vascular and cortical union. Considering that the greater majority of plasminogen-deficient mice did not achieve union by the termination of the studies, a longer study period will be required to test this hypothesis.

Development of heterotopic ossification in skeletal muscle adjacent to the fracture was both a striking and unexpected finding. Heterotopic ossification often occurs following musculoskeletal trauma associated with electrocution, burn/blast injuries, or with neurological injury (49-52). Although these conditions have been anecdotally associated with diminished fibrinolytic activity (53-55), there are no reports that suggest that plasmin(ogen) is directly involved in preventing heterotopic ossification. It has been determined that absence of uPA results in spontaneous heterotopic ossification in mice with Duschenne's muscular dystrophy, although it was not determined whether this was secondary to a deficiency of
Figure 7. Plasmin is required for hard-tissue callus union. $3 \mathrm{D} \mu \mathrm{CT}$ reconstruction of a displaced fracture at 42 DPF shows evidence of soft-tissue mineralization away from the fracture callus in $\mathrm{Plg}^{-/-}$mice (yellow arrowheads). Coronal and sagittal $2 \mathrm{D} \mu \mathrm{CT}$ slices of WT and $\mathrm{Plg}^{-1-}$ mouse femurs show cortical bridging by hard fracture callus (yellow pound symbols) in WT mice. In contrast, a failure to unite the proximal and distal hard-tissue callus was observed in $\mathrm{Plg}^{-1-}$ mice (red arrowheads). MSB stains demonstrate the presence of organized woven bone formation within the callus, and safranin 0-stained sections confirm complete cortical bridging in WT mice (black pound symbol), whereas the fracture gap in $\mathrm{Plg}^{-/-}$mice remains composed of chondroid soft-tissue callus (yellow asterisks) and fibrous tissue (yellow plus sign) without evidence of cortical bridging. Immunofluorescence microscopy for fibrin shows abundant fibrin deposition at the fracture site in $\mathrm{Plg}^{-1-}$ mice (red stain with DAPI blue counterstain, white arrowheads). Black boxes in safranin 0 sections indicate region displayed for fibrin immunofluorescence. $n=15$ for each genotype. White scale bars: $1 \mathrm{~mm}$ (top two rows), $500 \mu \mathrm{m}$ (bottom row); black scale bars: $1 \mathrm{~mm}$.

downstream plasmin activity (56). Moreover, fibrin can bind calcium phosphate and promote mineralization (and in fact has been used in bone graft substitutes for this property) (57). Heterotopic ossification was significantly reduced when fibrinogen levels were reduced in plasminogen-deficient mice $(P<0.05$; see Table 1$)$. Therefore, we posit that fibrin and plasmin are potential determinants of traumatic heterotopic ossification. Future studies are required to better define the precise mechanism by which plasminogen and fibrinogen contribute to heterotopic ossification following fracture.

Our results suggest a new paradigm for the roles of fibrin and plasmin during fracture repair. Fibrin is not essential for fracture repair, and indeed, fibrin must be timely and effectively removed to allow fracture vascularization and repair. Given that impaired fibrinolysis and vascular dysfunction are both seen in comorbidities associated with poor fracture repair (17-20, 23, 34-38) and that impaired angiogenesis is hypothesized to be a primary cause of delayed union or nonunion, our findings suggest that persistent or excessive fibrin deposition at the fracture site is the molecular mechanism of impaired fracture angiogenesis and subsequent delayed or nonunion in these conditions.

\section{Methods}

\section{Animals}

Homozygous breeding pairs of $\mathrm{Plg}^{-/-}$and $\mathrm{Fbg}^{-/-}$mice on a $\mathrm{C} 57 \mathrm{BL} / 6$ genetic background were previously described $(58,59)$; these were bred in the animal facility of Vanderbilt University with a 12-hour light/12-hour dark cycle. At the time of study, both fibrinogen- and plasminogen-deficient mice were 11 generations from the founding pair of mice. The C57BL/6 mouse WT strain, recommended by Jackson Laboratory as the control strain for comparison with $\mathrm{Plg}^{-/-}$and $\mathrm{Fbg}^{-/-}$mice, was obtained from Jackson Laboratory. To avoid sexrelated confounding effects on developmental bone growth and fracture repair, only male mice were used in this study. All mice were used for fracture study at 8 weeks of age.

\section{Murine femur fracture model}

Mice were placed under anesthesia using $60 \mathrm{mg} / \mathrm{kg}$ ketamine and 4 $\mathrm{mg} / \mathrm{kg}$ xylazine. The fur overlying the medial of the thigh was shaved and the skin prepped with betadine prior to making an incision. A 10to $12-\mathrm{mm}$ long medial incision of mid to distal femur was made, and 


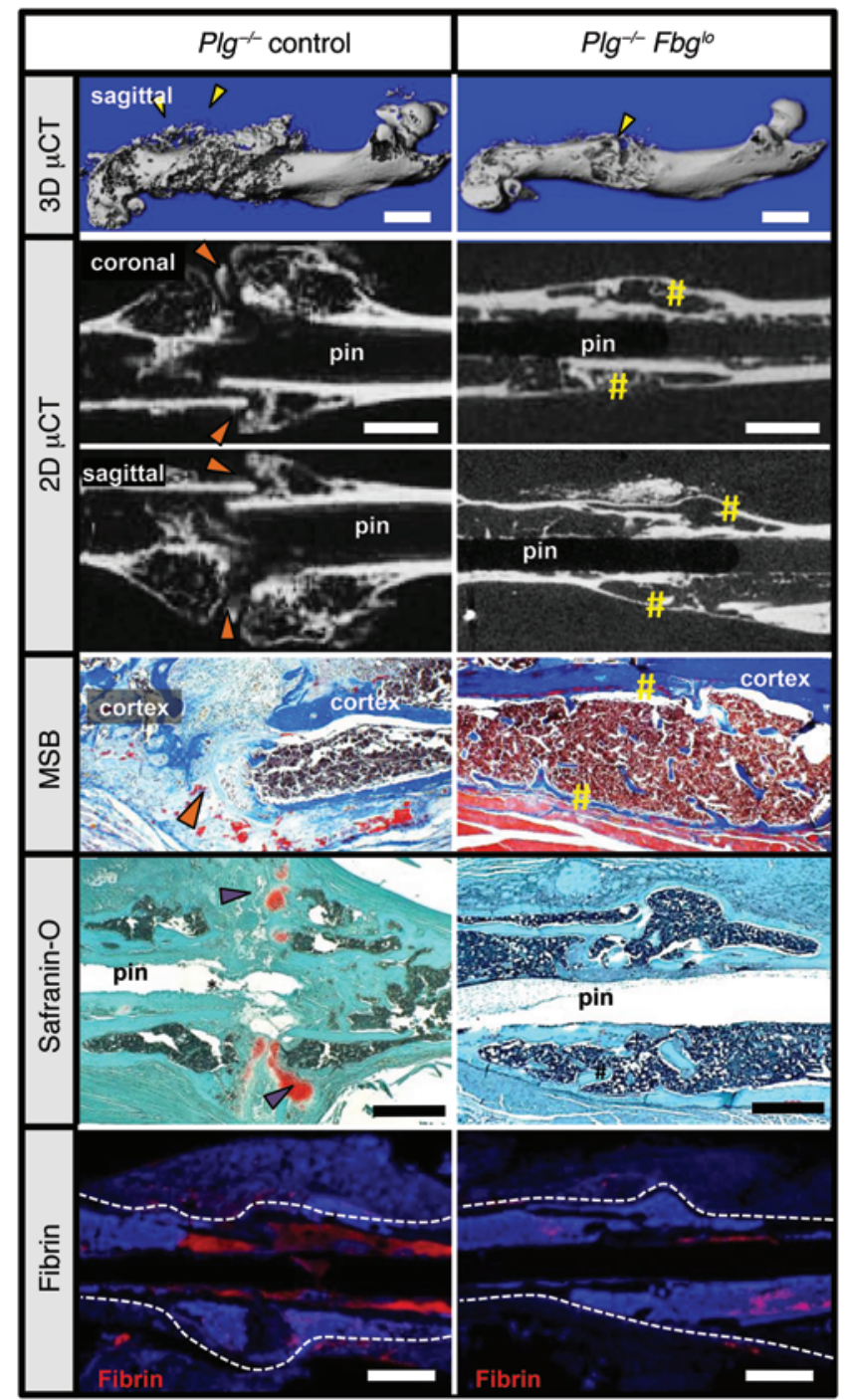

mid-shaft femur was exposed by blunt dissection of muscle. After patella was moved laterally, fracture was created by cutting the midshaft of the femur with fine scissors. A 23-gauge needle $(0.6414 \mathrm{~mm})$ was inserted into the intercondylar notch using a trephine technique and advanced through the intramedullary canal to the sub- or intertrochanteric femur. Before closure, we confirmed that the fracture was neither partial nor comminuted. The incision was closed by silk suture. Fracture repair was followed radiographically using a Faxitron $\mathrm{x}$-ray system (4 seconds at $35 \mathrm{kV}$ ) weekly. Mice were sacrificed at 14 and 42 days after surgery and samples processed for $\mu \mathrm{CT}$, MICROFIL (MV-122 Flow Tech Inc.), and histology.

\section{Imaging}

Gross pictures. The fractured femora were dissected after we sacrificed the mice. We removed the surrounding muscle around the femora. We carefully removed muscle using microforceps so as not to damage any mineralized tissues around the fracture site. After fixing the specimens in $4 \%$ paraformaldehyde, we took photographs with an Olympus dissecting microscope.

$X$-ray. X-ray was performed as previously described (60). Briefly, mice were placed in the prone position and imaged for 4 seconds
Figure 8. Fibrinogen knockdown rescues hard-tissue callus union. Representative $3 \mathrm{D}$ and $2 \mathrm{D} \mu \mathrm{CT}$ images, safranin $\mathrm{O}$-stained sections, and immunofluorescence microscopy for fibrin in $\mathrm{Plg}^{-/-}$and $\mathrm{Plg}^{-1-} \mathrm{Fbg}^{10}$ mice. 3D $\mu \mathrm{CT}$ images demonstrate heterotopic ossification (yellow arrowheads) and poorly macroscopically remodeled hard-tissue fracture callus in $\mathrm{Plg}^{-1-}$ mice for $42 \mathrm{DPF}$ formation. $2 \mathrm{D} \mu \mathrm{CT}$ of the fracture sites in $\mathrm{Plg}^{-1-} \mathrm{Fbg}^{10}$ mice shows cortical bridging by hard-tissue callus (yellow sharps), whereas this is not shown in $\mathrm{Plg}^{-1-}$ mice (orange arrowheads). Histological sections confirmed united fractures with the presence of reactive woven bone in $\mathrm{Plg}^{-1-} \mathrm{Fbg}^{10}$ mice in contrast to the disorganized callus with residual soft-tissue callus in $\mathrm{Plg}^{-1-}$ mice (purple arrowheads). Immunofluorescence for fibrin confirms markedly less fibrin in the fracture site in $\mathrm{Plg}^{-1-} \mathrm{Fbg} / \mathrm{l}$ mice (red stain, fibrin, with DAPI blue counterstain). White dotted line denotes border of the femur and fracture callus. Scale bars: $1 \mathrm{~mm} . n \geq 5$ for each genotype.

at $45 \mathrm{kV}$ using a Faxitron LX 60. Mice were sacrificed at various time points (7-42 days) following fracture.

Angiography. Perfusion with MICROFIL vascular contrast was conducted as previously described (61-64). Briefly, mice were euthanized and positioned supine; a thoracotomy extending into a laparotomy was performed. The left ventricle of the heart was cannulated using a 25-gauge butterfly needle. The inferior vena cava (IVC) was transected proximal to the liver and the entire vasculature subsequently perfused with $9 \mathrm{ml}$ of warm heparinized saline (100 units/ $\mathrm{ml}$ in $0.9 \%$ saline) through the left ventricle cannula to prevent erythrocyte aggregation and thrombosis. A perfusion pump (Braintree Scientific Inc.) was used to achieve consistent perfusion at the ratio of 2 $\mathrm{ml} / \mathrm{min}$. Exsanguination and anticoagulation were deemed complete upon widespread hepatic blanching with clear fluid extravasating from the IVC. Mice were then perfused with $9 \mathrm{ml}$ of $10 \%$ neutral buffered formalin at $2 \mathrm{ml} / \mathrm{min}$ followed by $3 \mathrm{ml}$ of MICROFIL vascular contrast polymer at $0.5 \mathrm{ml} / \mathrm{min}$. To best verify complete filling of the vasculature, gross images of the liver, the last organ to be perfused prior to extravasation through the IVC, were examined for extravascular pooling. Mice were excluded from the study if complete hepatic blanching prior to MICROFIL was not achieved, if contrast was not clearly or uniformly visible in the hepatic vasculature, or if extravascular pooling occurred. Due to the similarities in the density of bone and MICROFIL contrast, all fracture samples that were already taken by s-ray were then decalcified in 0.5 M EDTA, $\mathrm{pH} 8$, prior to $\mathrm{x}$-ray and $\mu \mathrm{CT}$ imaging.

$\mu C T$. $\mu \mathrm{CT}$ images were acquired ( $\mu \mathrm{CT} 40$, Scanco Medical) following specimen harvest of the fractured femurs at $55-\mathrm{kVp}, 145-\mathrm{uA}$, $20-0 \mathrm{~ms}$ integration, 500 projections per $180^{\circ}$ rotation, with a $20-\mu \mathrm{m}$ isotropic voxel size. After reconstruction, a volume of interest was selected comprising the medullary space starting at the center of fracture site and extending $0.5 \mathrm{~mm}$ additionally both distally and proximally. The bone tissue within the VOI was segmented from soft tissue using a threshold of 220 per thousand (or $450.7 \mathrm{mgHA} / \mathrm{cm}^{3}$ ), a Gaussian noise filter of 0.2 , and support of 1 . Bone volume and bone area were calculated using Scanco Medical evaluation software. A combination of $\mu \mathrm{CT}$ parameters was chosen to describe the material and geometrical properties of the callus. TMD was used for description of fracture repair. TMD is the average of attenuation value of all voxels above the threshold and within the total volume. This value has the units of $\mathrm{mgHA} / \mathrm{cm}^{3}$ because a hydroxyapatite phantom is scanned weekly, providing the conversion of attenuation to equivalent density of HA. pMOI and anisotropy describe the geometrical distribution of this material and are associated with torsional distribution strength. 


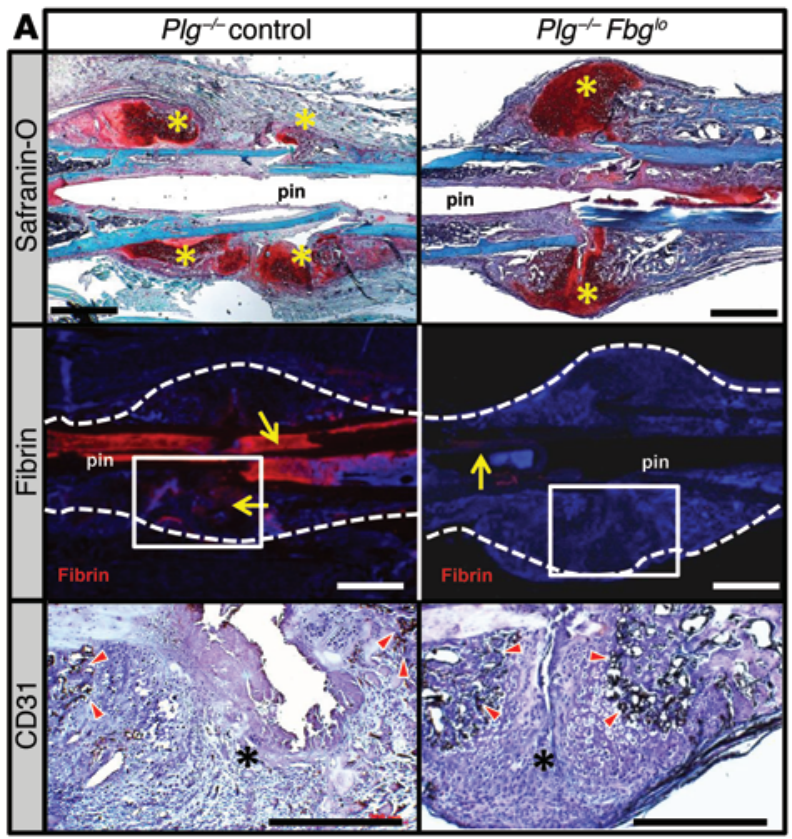

Figure 9. Fibrinogen knockdown rescues impaired callus formation and revascularization. (A) Representative histological sections of femoral fracture sites from $\mathrm{Plg}^{-1-}$ mice treated with ASO as a control and $\mathrm{Plg}^{-/-}$mice $\left(\mathrm{Plg}^{-/-}\right.$control; $\left.n=5\right)$ treated with an ASO against fibrinogen $\left(\mathrm{Plg}^{-1-} \mathrm{Fbg}^{10} ; n=10\right)$ at 14 DPF. Sections were stained with safranin $\mathrm{O}$ and assessed by immunofluorescence for fibrin and by immunohistochemistry for CD31. Whereas the fracture callus of $\mathrm{Plg}^{-1}$ mice is somewhat disorganized, with multiple foci of chondroid softtissue callus (safranin 0 , yellow asterisks), the callus in $\mathrm{Plg}^{-1-} \mathrm{Fbg}^{10}$ mice is more organized, with a central soft-tissue callus bordered proximally and distally by hard-tissue callus. There is markedly reduced fibrin deposition in the fracture callus of $\mathrm{Plg}^{-/-} \mathrm{Fbg}^{10}$ mice compared with $\mathrm{Plg}^{-1-}$ control mice (yellow arrows; white box denotes area shown for CD31 staining). CD31 highlights numerous CD31positive cells lining blood vessels in the hard-tissue callus of $\mathrm{Plg}^{-1-}$ $\mathrm{Fbg}^{10}$ mice (red arrowheads), with fewer vessels in $\mathrm{Plg}^{-/-}$mice (black asterisks denote areas of soft-tissue callus in fracture gap). Scale bars: $1 \mathrm{~mm}$. Statistical comparison (Student's $t$ test) of (B) fibrin deposition at fracture site, (C) number of CD31-positive vessels in the callus (left), and total area of CD31-positive vessels (right). $n \geq 5$ for each group. Four sections in each sample were averaged to constitute a single replicate $(1 n) .{ }^{*} P<0.01$. Error bars represent SEM.
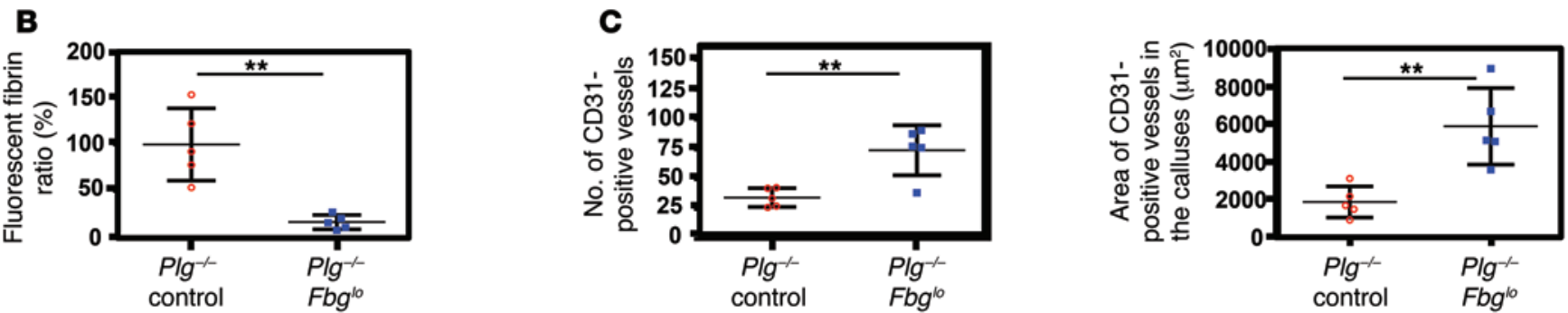

These parameters were determined by including all mineralized tissue within the outer perimeter of the fracture callus from $\mu \mathrm{CT}$ images by the Scanco Medical script for midshaft evaluation.

\section{Histological analysis}

Specimens removed for histology were fixed in $4 \%$ paraformaldehyde decalcified in 0.5 M EDTA (pH 8.0) for approximately 5 days. Subsequently, they were dehydrated in a graded series of ethanol, cleared, and embedded in paraffin. Each sample was sectioned sagittally at 6 $\mu \mathrm{m}$ and used for staining.

\section{Safranin orange/fast green stains (safranin 0)}

Paraffin-embedded tissue was sectioned onto slides and deparaffinized and rehydrated as for $\mathrm{H} \& \mathrm{E}$ above. Slides were placed in freshly filtered working Weigert's hematoxylin for 10 minutes and immediately washed in running tap water for 10 minutes. Slides were then placed in working $0.1 \%$ fast green solution for 5 minutes and rinsed quickly in $1 \%$ acetic acid for no more than 10 to 15 seconds. Slides were then placed in $0.1 \%$ safranin $\mathrm{O}$ solution for 5 minutes. Finally, slides were dehydrated through 2 changes of $95 \% \mathrm{EtOH}$ and $100 \% \mathrm{EtOH}$ for 3 minutes each and cleared in 2 changes of xylene for 5 minutes. Slides were then coverslipped with Permount.

\section{Immunohistochemistry}

Paraffin was removed from the slides using 2 xylene washes for 10 minutes each. The slides were then rehydrated in the following series of solutions: $100 \%$ EtOH twice for 2 minutes each, $90 \% \mathrm{EtOH}$ for 2 minutes, $80 \%$ EtOH for 2 minutes, $70 \%$ EtOH for 2 minutes, $\mathrm{dH}_{2} \mathrm{O}$ for 2 minutes. Antigen retrieval was performed using $0.1 \mathrm{M}$ citric acid and $0.1 \mathrm{M}$ sodium citrate. Slides were heated for about 2 minutes in the microwave. Subsequently, the endogenous peroxide was quenched with the $3 \% \mathrm{H}_{2} \mathrm{O}_{2}$ for 15 minutes. After washing the slide gently with PBS 3 times, the sections were then blocked for 30 minutes using blocking solution (TSA kit; PerkinElmer) to minimize nonspecific staining. The slides were immunostained for rabbit anti-mouse fibrin using a 1:1000 dilution of the primary antibody (fibrin) in the blocking solution and incubated overnight at $4^{\circ} \mathrm{C}$. Slides incubated without primary antibody served as negative controls. The slides were washed 3 times in TNT wash buffer for 5 minutes each. We applied biotin goat anti-rabbit Ig antibody (BD Biosciences - Pharmingen, 550338) for secondary antibody. After TSA amplification, the Dako EnVision+ HRP/DAB System (catalog K4007, Dako) was used to produce localized, visible staining. All slides were incubated for equal amounts of time. They were then rinsed in $\mathrm{dH}_{2} \mathrm{O}$ for 2 minutes, counterstained with Mayer's hematoxylin, and coverslipped. Slides were immunostained for rat anti-mouse CD31 using a 1:50 dilution of the primary antibody (CD31) in the blocking solution and incubated overnight at $4^{\circ} \mathrm{C}$. Slides incubated without primary antibody served as negative controls. Slides were washed 3 times in TNT wash buffer for 5 minutes each. We applied biotin goat anti-rat Ig antibody (BD Biosciences Pharmingen, 559286) for secondary antibody. After TSA amplification, the Dako EnVision+ HRP/DAB System (catalog K4007, Dako) 


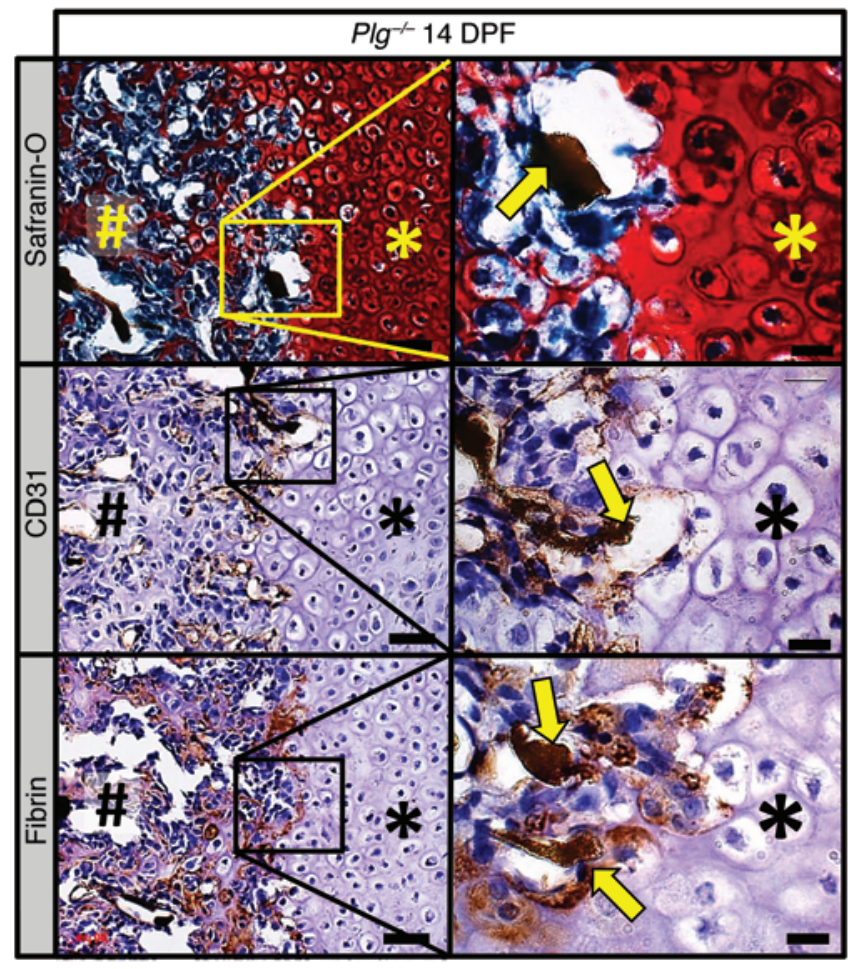

was used to produce localized, visible staining. All slides were incubated for equal amounts of time. They were then rinsed in $\mathrm{dH}_{2} \mathrm{O}$ for 2 minutes, counterstained with Mayer's hematoxylin, and coverslipped.

\section{Immunofluorescence microscopy}

After slides were deparaffinized and hydrated, sodium citrate antigen retrieval was performed using $0.1 \mathrm{M}$ citric acid and $0.1 \mathrm{M}$ sodium citrate. Slides were heated for 2 minutes in the microwave, cooled to room temperature and then washed gently with Tris-buffered saline (TBS). Slides were blocked (5\% BSA solution containing 10\% goat serum) and immunostained with rabbit anti-mouse fibrin(ogen) (1:1000) antibody (65) overnight at $4^{\circ} \mathrm{C}$. Slides were then washed and incubated with $10 \mu \mathrm{g} / \mathrm{ml}$ of Alexa Fluor 647-labeled anti-rabbit antibody (Life Technologies 792514) in blocking buffer for 1 hour. Slides were counterstained with DAPI and coverslipped using mounting solution (PolySciences); fluorescent images were taken (NIKON AZ100, upright wide-field microscope). Slides incubated without primary antibodies served as negative controls.

\section{van Gieson/von Kossa staining in plastic section}

Undecalcified femurs of each mouse were fixed in paraformaldehyde and dehydrated in ascending alcohol concentrations and then embedded in methylmethacrylate as previously described (66). Sections of $7-\mu \mathrm{m}$ thickness were cut on a Microtec rotation microtome (Techno$\mathrm{Med} \mathrm{GmbH}$ ). Sections were stained by van Gieson/von Kossa procedures as described. Undecalcified sections of $4 \mu \mathrm{m}$ were cut in the sagittal plane on a Microtec rotation microtome (Techno-Med GmbH).

\section{Quantification of soft-tissue callus size}

Hard- and soft-tissue callus, delineated by safranin O red staining, was traced on 5 histological step sections $200 \mu \mathrm{m}$ apart as previously described, with the following changes (67). To determine the orienta-
Figure 10. Fibrin is deposited at the interface between avascular soft-tissue callus and vascularized hard-tissue callus. Histological evaluation of the fracture callus of $\mathrm{Plg}^{-1-}$ mice at $14 \mathrm{DPF}$ discloses angiogram contrast-perfused blood vessels (safranin 0 , yellow arrow) at the interface of the soft-tissue callus (asterisks) and hard-tissue callus (pound symbols). Immunohistochemical staining for CD31 (brown staining) highlights thin-walled blood vessels filled with angiogram contrast material (CD31, yellow arrows) at the interface of soft- and hard-tissue callus. Immunohistochemistry also identifies fibrin (brown staining) at this interface surrounding angiogram contrast-perfused blood vessels (fibrin, yellow arrows). Immunohistochemistry slides were counterstained with hematoxylin. Scale bars: $50 \mu \mathrm{m}$ (left column); $20 \mu \mathrm{m}$ (right column). Representative of $n=5$.

tion of the 5 slides, the edge of the callus was visualized by identifying the first section with callus on both the medial and lateral femoral cortex, and the middle of the callus was determined by the pin space. Each of the specimen's 5 sections was measured by 3 blinded reviewers, and results were then expressed as $\mathrm{mm}^{2}$ of the soft-tissue callus area. Image quantification for the soft-tissue callus was performed using ImageJ (http://rsb.info.nih.gov/ij/).

\section{Quantification of fracture callus vascularity}

To assess vascularity of the fracture callus, immunohistochemical staining for CD31 was performed at 14 DPF. Photographs of the distal and proximal ends of the fracture callus were taken under low magnification $(\times 20)$, so that the entirety of fracture callus was collected. CD31 area was determined by using Photoshop (threshold 40) to select all CD31-positive staining from the background. CD31-positive staining was then imported into ImageJ, and the area of staining was calculated. To determine the number of CD31-positive vessels, 2 blinded observers counted CD31-positive vessels within the fracture callus. A vessel was defined as a structure with CD31 cells lining the lumen.

\section{ASO treatment}

ASO for fibrinogen (ISIS Pharmaceuticals Inc.) was administered to $\mathrm{Plg}^{-/-}$mice 2 weeks prior to fracture and throughout the course of this study at a concentration of $100 \mathrm{mg} / \mathrm{kg}$ subcutaneously weekly. Fibrinogen ASO (GCTTTGATCAGTTCTTTGGC) targets hepatic translation of the $\gamma$-chain of fibrinogen and has been shown to have no toxicity at this dose. As a control, the universal control ASO (CCTTCCCTGAAGGTTCCTCC), which has no homologies in the mouse genome, was administered subcutaneously at a concentration of $100 \mathrm{mg} / \mathrm{kg}$ weekly 2 weeks prior to fracture. Both ASOs were chemically modified with a phosphorothioate backbone that had 2'-O-methoxyethyl-modified nucleotides on the wings and a central deoxynucleotide gap. ASOs were synthesized using an Applied Biosystems 380B automated DNA synthesizer (Applied Biosystems) and purified as described previously (68). In order to identify the most potent fibrinogen ASOs for animal testing, ASOs were designed and tested in primary mouse hepatocytes for their ability to suppress mRNA levels of the respective targets.

\section{Fibrinogen ELISA}

To determine the effect of ASO for fibrinogen, we performed a fibrinogen ELISA. For collecting the plasma, we collected blood from mice using one-tenth volume of $0.1 \mathrm{M}$ sodium citrate as an anticoagulant. After the collection of the blood in the centrifuge tubes, blood was centrifuged at $1,500 \mathrm{~g}$ for 15 minutes at room temperature. Supernatant 
was collected and centrifuged again at $13,000 \mathrm{~g}$ for 15 minutes at room temperature. Plasma in the supernatant was stored at $-80^{\circ} \mathrm{C}$ until use. We measured the circulating fibrinogen levels using the manufacturer's instructions (Immunology Consultants Laboratory Inc.).

\section{FEA}

To establish whether fibrin is essential to fracture repair, the segmented $\mu \mathrm{CT}$ images of the callus from WT and $\mathrm{Fbg}^{-/}$mice at $42 \mathrm{DPF}$ were converted to finite element models for an elastic FEA solver using a built-in code (FE-software v1.13, Scanco Medical). After ensuring that the callus segment ( $5 \mathrm{~mm}$ above and below fracture line) was aligned in the $z$ or vertical direction (image stack rotated if tilted), one end was fully constrained (no movement) while the other end was prescribed a unit torque about the $z$-axis. Then, with the elastic modulus and Poisson's ratio equal to $12 \mathrm{GPa}$ and 0.3 for all mineralized tissue, the predicted callus strength was determined for the prescribed boundary conditions, assuming failure occurred when $2 \%$ of bone volume exceed 7000 microstrain. This approach is similar to other $\mu$ CT-FEA studies involving torsion of rat femur callus (69) and compression testing of mouse vertebra (70). Since we assumed homogeneous material properties with elastic failure criteria, $\mu \mathrm{CT}$-FEA effectively assessed the contribution of structure (callus size and union), not mineralization, to callus strength.

\section{Radiographic quantification of fracture repair}

We quantified fracture repair by measuring the 4 criteria: (a) mineralization, (b) organization, (c) union, and (d) remodeling. Samples were scored in a binary fashion with 0 meaning "does not meet the criteria" and 1 meaning "meets the criteria." Both the anterior and posterior femur were scored, allowing for each radiograph to have a possibility of 8 total points. All x-rays were assessed in a blinded manner by 3 orthopedic clinicians from 1 to 6 weeks after fracture.

\section{Statistics}

Comparisons among the groups were performed using 1-way ANOVA with the least significant difference procedure used for analyzing 2 or multiple groups, respectively. $P<0.05$ was considered significant for the differences between mean values.

\section{Study approval}

All animal protocols were reviewed and approved by the Institutional Animal Care and Use Committee (IACUC) of Vanderbilt University Medical Center.

\section{Acknowledgments}

Funding was provided by the Musculoskeletal Transplantation Foundation, the Orthopaedic Trauma Association, a Vanderbilt Orthopaedic Institute research grant, and the Caitlin Lovejoy Fund.

Address correspondence to: Jonathan G. Schoenecker, 4202 Doctors' Office Tower, 2200 Children's Way, Nashville, Tennessee 37232-9565, USA. Phone: 615.936.3080; E-mail:Jon.Schoenecker@ vanderbilt.edu.
1. Yuasa M, et al. The temporal and spatial development of vascularity in a healing displaced fracture. Bone. 2014;67:208-221.

2. Gerstenfeld LC, Cullinane DM, Barnes GL, Graves DT, Einhorn TA. Fracture healing as a post-natal developmental process: molecular, spatial, and temporal aspects of its regulation. JCell Biochem. 2003;88(5):873-884.

3. Rockwood CA, Green DP, Bucholz RW. Rockwood and Green's Fractures In Adults. Philadelphia, Pennsylvania, USA: Wolters Kluwer Health/Lippincott Williams \& Wilkins; 2010.

4. Anitua E, Andia I, Ardanza B, Nurden P, Nurden AT. Autologous platelets as a source of proteins for healing and tissue regeneration. Thromb Haemost. 2004;91(1):4-15.

5. Martino MM, Briquez PS, Ranga A, Lutolf MP, Hubbell JA. Heparin-binding domain of fibrin(ogen) binds growth factors and promotes tissue repair when incorporated within a synthetic matrix. Proc Natl Acad Sci U S A. 2013;110(12):4563-4568.

6. Sahni A, Francis CW. Vascular endothelial growth factor binds to fibrinogen and fibrin and stimulates endothelial cell proliferation. Blood. 2000;96(12):3772-3778.

7. Kolar P, et al. The early fracture hematoma and its potential role in fracture healing. Tissue Eng Part B Rev. 2010;16(4):427-434.

8. Key JA, Conwell HE. The Management OfFractures, Dislocations, And Sprains. St. Louis, Missouri, USA: The C.V. Mosby Company; 1946.

9. Bugge TH, et al. Urokinase-type plasminogen activator is effective in fibrin clearance in the absence of its receptor or tissue-type plas- minogen activator. Proc Natl Acad Sci U S A. 1996;93(12):5899-5904.

10. Romer J, et al. Impaired wound healing in mice with a disrupted plasminogen gene. Nat Med. 1996;2(3):287-292.

11. Bugge TH, Kombrinck KW, Flick MJ, Daugherty CC, Danton MJ, Degen JL. Loss of fibrinogen rescues mice from the pleiotropic effects of plasminogen deficiency. Cell. 1996;87(4):709-719.

12. Cole HA, et al. Fibrin accumulation secondary to loss of plasmin-mediated fibrinolysis drives inflammatory osteoporosis in mice. Arthritis Rheumatol. 2014;66(8):2222-2233.

13. Gunnar BJ, et al. United States Bone and Joint Initiative: The Burden of Musculoskeletal Diseases in the United States. 2nd ed. Park Ridge, Illinois, USA: American Academy of Orthopaedic Surgeons; 2011.

14. Einhorn TA. Enhancement of fracture-healing J Bone Joint Surg Am. 1995;77(6):940-956.

15. Ebraheim NA, Martin A, Sochacki KR, Liu J. Nonunion of distal femoral fractures: a systematic review. Orthop Surg. 2013;5(1):46-50.

16. Robinson CM, Court-Brown CM, McQueen MM, Wakefield AE. Estimating the risk of nonunion following nonoperative treatment of a clavicular fracture. J Bone Joint Surg Am. 2004; 86-A(7):1359-1365.

17. Cobb TK, Gabrielsen TA, Campbell DC 2nd, Wallrichs SL, Ilstrup DM. Cigarette smoking and nonunion after ankle arthrodesis. Foot Ankle Int. 1994;15(2):64-67.

18. Macey LR, Kana SM, Jingushi S, Terek RM, Borretos J, Bolander ME. Defects of early fracturehealing in experimental diabetes. J Bone Joint
Surg Am. 1989;71(5):722-733.

19. Gruber R, Koch H, Doll BA, Tegtmeier F, Einhorn TA, Hollinger JO. Fracture healing in the elderly patient. Exp Gerontol. 2006;41(11):1080-1093.

20. Kline AJ, Gruen GS, Pape HC, Tarkin IS, Irrgang JJ, Wukich DK. Early complications following the operative treatment of pilon fractures with and without diabetes. Foot Ankle Int. 2009;30(11):1042-1047.

21. Rodriguez EK, et al. Predictive factors of distal femoral fracture nonunion after lateral locked plating: a retrospective multicenter case-control study of 283 fractures. Injury. 2014;45(3):554-559.

22. Foulk DA, Szabo RM. Diaphyseal humerus fractures: natural history and occurrence of nonunion. Orthopedics. 1995;18(4):333-335.

23. Castillo RC, Bosse MJ, MacKenzie EJ, Patterson $\mathrm{BM}$, Group LS. Impact of smoking on fracture healing and risk of complications in limb-threatening open tibia fractures. JOrthop Trauma. 2005;19(3):151-157.

24. Meade TW, Chakrabarti R, Haines AP, North WRS, Stirling Y. Characteristics affecting fibrinolytic activity and plasma fibrinogen concentrations. Br Med J. 1979;1(6157):153-156.

25. Stepien E, Miszalski-Jamka T, Kapusta P, Tylko G, Pasowicz M. Beneficial effect of cigarette smoking cessation on fibrin clot properties. J Thromb Thrombolysis. 2011;32(2):177-182.

26. Pandolfi A, et al. Plasminogen activator inhibitor type 1 is increased in the arterial wall of type II diabetic subjects. Arterioscler Thromb Vasc Biol. 2001;21(8):1378-1382.

27. Maes C, et al. Osteoblast precursors, but not mature osteoblasts, move into developing and 
fractured bones along with invading blood vessels. Dev Cell. 2010;19(2):329-344.

28. Gailit J, Clarke C, Newman D, Tonnesen MG, Mosesson MW, Clark RA. Human fibroblasts bind directly to fibrinogen at RGD sites through integrin $\alpha(\mathrm{v}) \beta 3$. Exp Cell Res. 1997;232(1):118-126.

29. Beamer B, Hettrich C, Lane J. Vascular endothelial growth factor: an essential component of angiogenesis and fracture healing. HSS J. 2010;6(1):85-94.

30. Gerber HP, Vu TH, Ryan AM, Kowalski J, Werb Z, Ferrara N. VEGF couples hypertrophic cartilage remodeling, ossification and angiogenesis during endochondral bone formation. Nat Med. 1999;5(6):623-628.

31. Harper J, Klagsbrun M. Cartilage to bone - angiogenesis leads the way. Nat Med. 1999;5(6):617-618.

32. Brookes M, Landon DN. The juxta-epiphysial vessels in the long bones of foetal rats. J Bone Joint Surg Br. 1964;46:336-345.

33. Hausman MR, Schaffler MB, Majeska RJ. Prevention of fracture healing in rats by an inhibitor of angiogenesis. Bone. 2001;29(6):560-564.

34. Burns DM. Epidemiology of smoking-induced cardiovascular disease. Prog Cardiovasc Dis. 2003;46(1):11-29.

35. Grundy SM, et al. and Sowers JR. Diabetes and cardiovascular disease: a statement for healthcare professionals from the American Heart Association. Circulation. 1999;100(10):1134-1146.

36. Meigs JB. Epidemiology of type 2 diabetes and cardiovascular disease: translation from population to prevention: the Kelly West award lecture 2009. Diabetes Care. 2010;33(8):1865-1871.

37. Purnell JQ, Zinman B, Brunzell JD, Group DER. The effect of excess weight gain with intensive diabetes mellitus treatment on cardiovascular disease risk factors and atherosclerosis in type 1 diabetes mellitus: results from the Diabetes Control and Complications Trial/Epidemiology of Diabetes Interventions and Complications Study (DCCT/ EDIC) study. Circulation. 2013;127(2):180-187.

38. Willigendael EM, et al. Influence of smoking on incidence and prevalence of peripheral arterial disease. J Vasc Surg. 2004;40 (6):1158-1165.

39. Hammond JD, Verel D. Observations on the distribution and biological half-life of human fibrinogen. Br J Haematol. 1959;5:431-438.

40. Ploplis VA, French EL, Carmeliet P, Collen D, Plow EF. Plasminogen deficiency differentially affects recruitment of inflammatory cell populations in mice. Blood.1998;91(6):2005-2009.

41. Wu AC, Raggatt LJ, Alexander KA, Pettit AR. Unraveling macrophage contributions to bone repair. Bonekey Rep. 2013;2:373.

42. Khalil N, Corne S, Whitman C, Yacyshyn H. Plas- min regulates the activation of cell-associated latent TGF- $\beta 1$ secreted by rat alveolar macrophages after in vivo bleomycin injury. Am J Respir Cell Mol Biol. 1996;15(2):252-259.

43. Yee JA, Yan L, Dominguez JC, Allan EH, Martin TJ. Plasminogen-dependent activation of latent transforming growth factor beta (TGF $\beta$ ) by growing cultures of osteoblast-like cells. JCell Physiol. 1993;157(3):528-534.

44. Roth D, et al. Plasmin modulates vascular endothelial growth factor-A-mediated angiogenesis during wound repair. Am J Pathol. 2006;168(2):670-684.

45. Schoenecker J, et al. 2010 Young Investigator Award winner: Therapeutic aprotinin stimulates osteoblast proliferation but inhibits differentiation and bone matrix mineralization. Spine. 2010;35(9):1008-1016.

46. Kawao N, et al. Plasminogen plays a crucial role in bone repair. JBone Miner Res. 2013;28(7):1561-1574

47. Daci E, Udagawa N, Martin TJ, Bouillon R, Carmeliet $\mathrm{G}$. The role of the plasminogen system in bone resorption in vitro. J Bone Miner Res. 1999;14(6):946-952.

48. Everts V, et al. Plasminogen activators are involved in the degradation of bone by osteoclasts. Bone. 2008;43(5):915-920.

49. Potter BK, et al. Heterotopic ossification following combat-related trauma. J Bone Joint Surg Am. 2010;92(suppl 2):74-89.

50. Forsberg JA, Davis TA, Elster EA, Gimble JM. Burned to the bone. Sci Transl Med. 2014;6(255):255fs37.

51. Sakellariou VI, Grigoriou E, Mavrogenis AF, Soucacos PN, Papagelopoulos PJ. Heterotopic ossification following traumatic brain injury and spinal cord injury: insight into the etiology and pathophysiology. J Musculoskelet Neuronal Interact. 2012;12(4):230-240.

52. Cipriano CA, Pill SG, Keenan MA. Heterotopic ossification following traumatic brain injury and spinal cord injury. J Am Acad Orthop Surg. 2009;17(11):689-697.

53. Aoki K, et al. Elevation of plasma free PAI-1 levels as an integrated endothelial response to severe burns. Burns. 2001;27(6):569-575.

54. Hofstra JJ, et al. Pulmonary activation of coagulation and inhibition of fibrinolysis after burn injuries and inhalation trauma. J Trauma. 2011;70(6):1389-1397.

55. Winther K, Gleerup G, Snorrason K, BieringSorensen F. Platelet function and fibrinolytic activity in cervical spinal cord injured patients. Thromb Res. 1992;65(3):469-474.

56. Suelves M, et al. uPA deficiency exacerbates muscular dystrophy in MDX mice. J Cell Biol. 2007;178(6):1039-1051.
57. Douglas TE, et al. Enzymatically induced mineralization of platelet-rich fibrin. J Biomed Mater Res A. 2012;100(5):1335-1346.

58. Bugge TH, Flick MJ, Daugherty CC, Degen JL. Plasminogen deficiency causes severe thrombosis but is compatible with development and reproduction. Genes Dev. 1995;9(7):794-807.

59. Suh TT, et al. Resolution of spontaneous bleeding events but failure of pregnancy in fibrinogendeficient mice. Genes Dev. 1995;9(16):2020-2033.

60. O'Neill KR, et al. Micro-computed tomography assessment of the progression of fracture healing in mice. Bone. 2012;50(6):1357-1367.

61. Cole HA, Yuasa M, Hawley G, Cates JM, Nyman JS, Schoenecker JG. Differential development of the distal and proximal femoral epiphysis and physis in mice. Bone. 2013;52(1):337-346.

62. Duvall CL, Taylor WR, Weiss D, Guldberg RE. Quantitative microcomputed tomography analysis of collateral vessel development after ischemic injury. Am J Physiol Heart Circ Physiol. 2004;287(1):H302-H310.

63. Duvall CL, Taylor WR, Weiss D, Wojtowicz AM, Guldberg RE. Impaired angiogenesis, early callus formation, and late stage remodeling in fracture healing of osteopontin-deficient mice. J Bone Miner Res. 2007;22(2):286-297.

64. Dhillon RS, et al. PTH-enhanced structural allograft healing is associated with decreased angiopoietin-2-mediated arteriogenesis, mast cell accumulation, and fibrosis. JBone Miner Res. 2013;28(3):586-597.

65. Flick MJ, Du X, Degen JL. Fibrin(ogen)- $\alpha$ M $\beta 2$ interactions regulate leukocyte function and innate immunity in vivo. Exp Biol Med (Maywood). 2004;229(11):1105-1110.

66. Lehmann W, et al. Absence of mouse pleiotrophin does not affect bone formation in vivo. Bone. 2004;35(6):1247-1255.

67. Gerstenfeld LC, et al. Impaired fracture healing in the absence of TNF-alpha signaling: the role of TNF-alpha in endochondral cartilage resorption. J Bone Miner Res. 2003;18(9):1584-1592.

68. Baker BF, et al. 2'-O-(2-Methoxy)ethyl-modified anti-intercellular adhesion molecule 1 (ICAM-1) oligonucleotides selectively increase the ICAM-1 mRNA level and inhibit formation of the ICAM-1 translation initiation complex in human umbilical vein endothelial cells. J Biol Chem. 1997;272(18):11994-12000.

69. Shefelbine SJ, et al. Prediction of fracture callus mechanical properties using micro-CT images and voxel-based finite element analysis. Bone. 2005;36(3):480-488.

70. Nyman JS, et al. Predicting mouse vertebra strength with micro-computed tomography-derived finite element analysis. Bonekey Rep. 2015;4:664. 